\title{
Involvement of Members of the Cadherin Superfamily in Cancer
}

\author{
Geert Berx ${ }^{1,2}$ and Frans van Roy ${ }^{2,3}$ \\ ${ }^{1}$ Molecular and Cellular Oncology Unit, Department for Molecular Biomedical Research, VIB, Ghent, Belgium \\ ${ }^{2}$ Department of Biomedical Molecular Biology, Ghent University, Ghent, Belgium \\ ${ }^{3}$ Molecular Cell Biology Unit, Department for Molecular Biomedical Research, VIB, Ghent, Belgium \\ Correspondence: f.vanroy@dmbr.vib-ugent.be
}

We review the role of cadherins and cadherin-related proteins in human cancer. Cellular and animal models for human cancer are also dealt with whenever appropriate. E-cadherin is the prototype of the large cadherin superfamily and is renowned for its potent malignancy suppressing activity. Different mechanisms for inactivating E-cadherin/CDH1 have been identified in human cancers: inherited and somatic mutations, aberrant protein processing, increased promoter methylation, and induction of transcriptional repressors such as Snail and ZEB family members. The latter induce epithelial mesenchymal transition, which is also associated with induction of "mesenchymal" cadherins, a hallmark of tumor progression. VE-cadherin/CDH5 plays a role in tumor-associated angiogenesis. The atypical T-cadherin/ $\mathrm{CDH} 13$ is often silenced in cancer cells but up-regulated in tumor vasculature. The review also covers the status of protocadherins and several other cadherin-related molecules in human cancer. Perspectives for emerging cadherin-related anticancer therapies are given.

\section{INTRODUCTION-DYSREGULATION OF CADHERIN FAMILY MEMBERS IN CANCER}

Cell-cell adhesion determines cell polarity and participates in cell differentiation and in establishment and maintenance of tissue homeostasis. During oncogenesis, this organized adhesion is disturbed by genetic and epigenetic changes, resulting in changes in signaling, loss of contact inhibition, and altered cell migration and stromal interactions. A major class of cell-cell adhesion molecules is the cadherin superfamily. Its prototypic member, E-cadherin, was characterized as a potent suppressor of invasion and metastasis in seminal studies dating back to the 1990 s (reviewed by van Roy and Berx 2008). Since then, many more cadherins and cadherinrelated proteins have been identified (Fig. 1) (reviewed by Hulpiau and van Roy 2009), and an increasing number has been implicated in cancer as putative tumor suppressors or as proto-oncogenic proteins. Here we discuss the structural and functional aberrations of cadherin family members in cancer and their roles in cancer initiation and progression.

\section{E-CADHERIN}

Most human tumors are carcinomas derived from epithelial tissues, in which E-cadherin is

Editors: W. James Nelson and Elaine Fuchs

Additional Perspectives on Cell Junctions available at www.cshperspectives.org

Copyright (C) 2009 Cold Spring Harbor Laboratory Press; all rights reserved; doi: 10.1101/cshperspect.a003129

Cite this article as Cold Spring Harb Perspect Biol 2009;1:a003129 


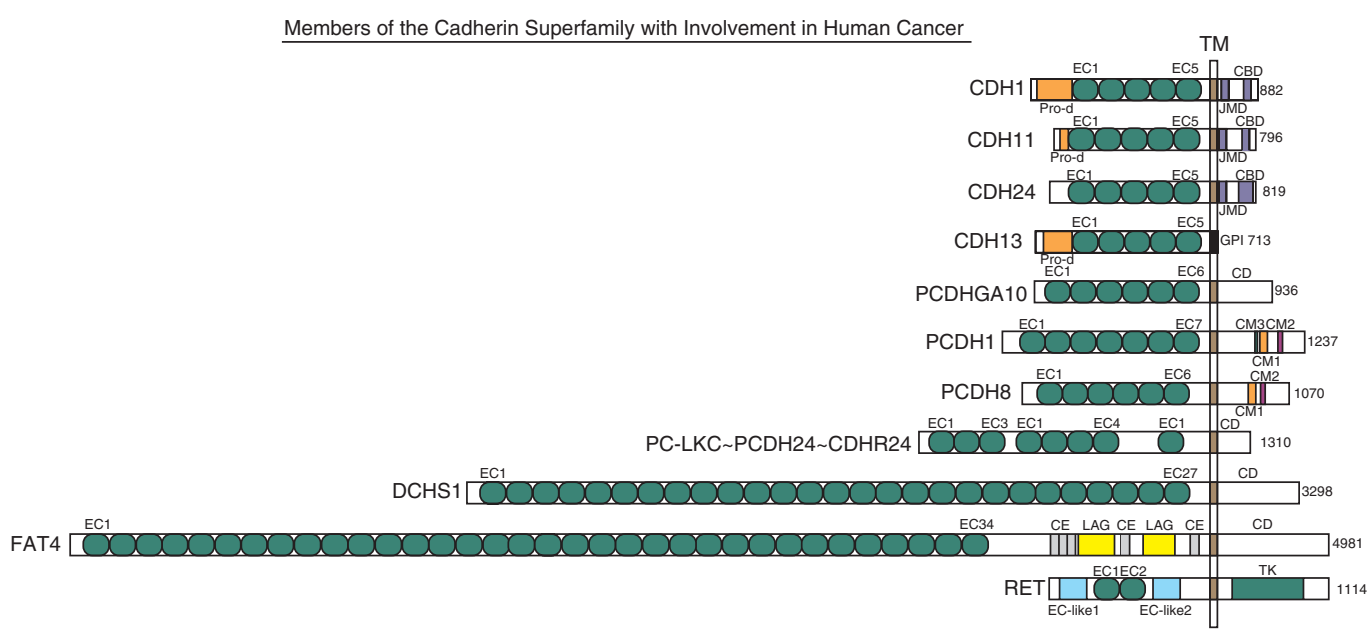

Figure 1. Schematic overview of representative human members of the cadherin superfamily with reported involvement in cancer (modified after Hulpiau and van Roy 2009). All proteins are drawn to scale and aligned at their transmembrane domain (TM). Their total sizes are indicated on the right (number of amino acid residues). The following protein domains are shown: CBD, (conserved cadherin-specific) catenin binding domain; CD, unique cytoplasmic domain; CE, Cysteine-rich EGF repeat-like domain; CM1 to $\mathrm{CM} 3$, conserved motifs in the CDs of $\delta$-protocadherins; EC, extracellular cadherin repeat; GPI, glycosylphosphatidylinositol anchor; JMD, (conserved cadherin-specific) juxtamembrane domain; LAG, laminin A globular domain; Pro-d, prodomain; TK, tyrosine kinase domain. On the basis of a phylogenetic analysis (Hulpiau and van Roy 2009), it was proposed that protocadherin LKC (PC-LKC or protocadherin-24) should be renamed (CDHR24).

the prototypic cadherin. Epithelial tumors often lose E-cadherin partially or completely as they progress toward malignancy (reviewed by Birchmeier and Behrens 1994; Christofori and Semb 1999; Strumane et al. 2004). Epithelial ovarian cancers are exceptional because expression of E-cadherin in inclusion cysts, derived from ovarian surface epithelium with little or no E-cadherin, appears to be essential for tumorigenesis in this organ (Sundfeldt 2003; Naora and Montell 2005). Another exception is inflammatory breast cancer, a distinct and aggressive form of breast cancer in which the expression of E-cadherin is consistently elevated regardless of the histologic type or molecular profile of the tumor (Table 1) (Alpaugh et al. 1999; Kleer et al. 2001). However, most studies have shown both strong anti-invasive and antimetastatic roles for E-cadherin (Frixen et al. 1991; Vleminckx et al. 1991; Perl et al. 1998). The possible functional implications, which were reviewed recently (Jeanes et al. 2008), include the sequestering of $\beta$-catenin in an E-cadherin-catenin adhesion complex (Fig. 3), leading to inhibition of its function in the canonical Wnt pathway (Fig. 4), besides inhibition of EGF receptor signaling and contribution to epithelial apicobasal polarization. We focus here on the different mechanisms for E-cadherin inactivation in malignant tumors, which include mutations, epigenetic silencing, and increased endocytosis and proteolysis (Fig. 2; Table 1).

\section{Loss of Heterozygosity and Inactivating Mutations in Cancer}

Studies on loss of heterozygosity ( $\mathrm{LOH}$ ) of chromosome 16q21-22 hinted at a role for E-cadherin in human cancer (Fig. 2; Table 1). Following the mapping of the human Ecadherin gene $\mathrm{CDH1}$ to chromosome 16q22.1 (Natt et al. 1989; Berx et al. 1995b), several studies showed frequent $\mathrm{LOH}$ of $16 \mathrm{q}$ in gastric, prostate, hepatocellular and esophageal carcinomas (reviewed by Strathdee 2002; 
$\underset{\substack{\text { PERSPECTIVES } \\ \mathbb{C}_{\infty}^{\infty}}}{\infty} \frac{\text { Cold Spring Harbor Perspectives in Biology }}{\text { www.cshperspectives.org }}$

Table 1. Representative abnormalities of cadherin superfamily members in cancer

\begin{tabular}{|c|c|c|c|c|c|}
\hline Protein & Human gene & $\begin{array}{l}\text { Tumor-associated } \\
\text { abnormalities }\end{array}$ & Tumor type ${ }^{1}$ & Clinical correlates $^{2}$ & Selected references \\
\hline \multirow[t]{6}{*}{ E-cadherin } & $\mathrm{CDH} 1$ & $\mathrm{LOH}$ & Numerous & Malignant progression & $\begin{array}{l}\text { (Reviewed in Strumane et al. } \\
\text { 2004) }\end{array}$ \\
\hline & & Promoter methylation & Numerous & Malignant progression & $\begin{array}{l}\text { (Reviewed in Strumane et al. } \\
\text { 2004) }\end{array}$ \\
\hline & & Germline mutations & $\begin{array}{l}\text { Gastric (DGC) } \\
\text { Breast (ILC) }\end{array}$ & $\begin{array}{l}\text { Hereditary diffuse gastric } \\
\text { cancer (HDGC) syndrome }\end{array}$ & (Guilford et al. 1998) \\
\hline & & Somatic mutations & $\begin{array}{l}\text { Breast (ILC) } \\
\text { Gastric (DGC) } \\
\text { Pancreas }\end{array}$ & Highly invasive growth pattern & (Berx et al. 1998) \\
\hline & & Up-regulated expression & $\begin{array}{l}\text { Epithelial ovarian } \\
\text { cancer }\end{array}$ & Tumorigenesis & $\begin{array}{l}\text { (Reviewed in Sundfeldt 2003; } \\
\text { Naora and Montell 2005) }\end{array}$ \\
\hline & & Overexpression & Breast (IBC) & $\begin{array}{l}\text { Promotes tumor emboli } \\
\text { formation }\end{array}$ & (Kleer et al. 2001) \\
\hline $\mathrm{N}$-cadherin & $\mathrm{CDH} 2$ & $\begin{array}{l}\text { Up-regulation (cadherin } \\
\text { switching) }\end{array}$ & $\begin{array}{l}\text { Breast } \\
\text { Pancreatic } \\
\text { Prostate } \\
\text { Melanoma }\end{array}$ & $\begin{array}{l}\text { Enhanced migration and } \\
\text { invasion, increased } \\
\text { metastasis; poor prognosis }\end{array}$ & $\begin{array}{l}\text { (Reviewed in Hazan et al. 2004; } \\
\text { Wheelock et al. 2008) }\end{array}$ \\
\hline \multirow[t]{2}{*}{ P-cadherin } & $\mathrm{CDH} 3$ & $\begin{array}{l}\text { Up-regulation (cadherin } \\
\text { switching) }\end{array}$ & $\begin{array}{l}\text { Breast } \\
\text { Gastric } \\
\text { Pancreatic (PDAC) }\end{array}$ & $\begin{array}{l}\text { Enhanced migration and } \\
\text { invasion, poor prognosis }\end{array}$ & $\begin{array}{l}\text { (Paredes et al. 2005; } \\
\text { Taniuchi et al. 2005) }\end{array}$ \\
\hline & & Down-regulation & Melanoma & $\begin{array}{l}\text { Increased invasion and } \\
\text { metastasis }\end{array}$ & (Sanders et al. 1999) \\
\hline R-cadherin & $\mathrm{CDH} 4$ & Promoter methylation & $\begin{array}{l}\text { Colorectal } \\
\text { Gastric }\end{array}$ & Early event & (Miotto et al. 2004) \\
\hline $\begin{array}{l}\text { Cadherin-11 = } \\
\text { OB-cadherin }\end{array}$ & $\mathrm{CDH} 11$ & $\begin{array}{l}\text { Up-regulation (cadherin } \\
\text { switching) }\end{array}$ & $\begin{array}{l}\text { Breast } \\
\text { Prostate }\end{array}$ & $\begin{array}{l}\text { High grade cancer; prostate } \\
\text { cancer metastasis to bone }\end{array}$ & $\begin{array}{l}\text { (Bussemakers et al. 2000; } \\
\text { Tomita et al. 2000; Chu } \\
\text { et al. 2008) }\end{array}$ \\
\hline VE-cadherin & $\mathrm{CDH} 5$ & Overexpression & Melanoma & $\begin{array}{l}\text { Vasculogenic mimicry; } \\
\text { malignant progression }\end{array}$ & $\begin{array}{l}\text { (Hendrix et al. 2001) } \\
\text { (Continued) }\end{array}$ \\
\hline
\end{tabular}




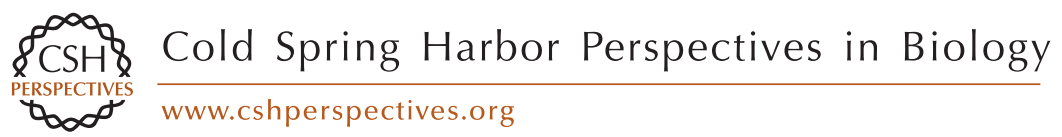

\begin{tabular}{|c|c|c|c|c|c|}
\hline Protein & Human gene & $\begin{array}{c}\text { Tumor-associated } \\
\text { abnormalities }\end{array}$ & Tumor type $^{1}$ & Clinical correlates $^{2}$ & Selected references \\
\hline \multirow[t]{16}{*}{ T-cadherin } & \multirow[t]{16}{*}{$\mathrm{CDH} 13$} & Decreased expression & Breast & Increased tumorigenesis & (Lee 1996) \\
\hline & & Promoter methylation & $\begin{array}{l}\text { Breast } \\
\text { Lung (NSCLC) }\end{array}$ & \multirow{9}{*}{$\begin{array}{l}\text { Increased tumorigenesis; } \\
\text { malignant progression; early } \\
\text { recurrence; poor prognosis }\end{array}$} & \multirow{9}{*}{$\begin{array}{l}\text { (Sato et al. 1998; Maruyama } \\
\text { et al. 2001; Toyooka et al. } \\
\text { 2001; Toyooka et al. 2002; } \\
\text { Roman-Gomez et al. 2003; } \\
\text { Hibi et al. 2004; Sakai et al. } \\
\text { 2004; Kim et al. 2005; Wang } \\
\text { et al. 2007; Brock et al. 2008; } \\
\text { Jin et al. 2008; Yan et al. 2008) }\end{array}$} \\
\hline & & & Prostate & & \\
\hline & & & $\begin{array}{l}\text { Colon (adenomas and } \\
\text { CRC) }\end{array}$ & & \\
\hline & & & Pancreas & & \\
\hline & & & Gastric & & \\
\hline & & & $\mathrm{HCC}$ & & \\
\hline & & & $\begin{array}{l}\text { Esophageal } \\
\text { adenocarcinoma }\end{array}$ & & \\
\hline & & & Bladder & & \\
\hline & & & $\begin{array}{l}\text { Chronic myeloid } \\
\text { leukemia }\end{array}$ & & \\
\hline & & \multirow{4}{*}{$\begin{array}{l}\text { LOH and promoter } \\
\text { methylation }\end{array}$} & Ovary & \multirow{4}{*}{$\begin{array}{l}\text { Tumor invasion; increased } \\
\text { cell proliferation and } \\
\text { resistance to apoptosis }\end{array}$} & \multirow{4}{*}{$\begin{array}{l}\text { (Kawakami et al. 1999; Takeuchi } \\
\text { et al. 2002a; Takeuchi et al. } \\
\text { 2002b; Ogama et al. 2004; } \\
\text { Chan et al. 2008) }\end{array}$} \\
\hline & & & Skin (BCC and SCC) & & \\
\hline & & & $\begin{array}{l}\text { Diffuse large B cell } \\
\text { lymphoma }\end{array}$ & & \\
\hline & & & $\mathrm{HCC}$ & & \\
\hline & & \multirow{2}{*}{$\begin{array}{l}\text { Expression in } \\
\text { intratumoral } \\
\text { endothelium }\end{array}$} & $\begin{array}{l}\text { Tumor models } \\
\text { HCC }\end{array}$ & \multirow{2}{*}{$\begin{array}{l}\text { Adiponectin-(co)receptor; } \\
\text { increased angiogenesis and } \\
\text { tumor progression }\end{array}$} & $\begin{array}{l}\text { (Wyder et al. 2000; Adachi et al. } \\
\text { 2006; Philippova et al. 2006; }\end{array}$ \\
\hline & & & & & $\begin{array}{l}\text { Riou et al. 2006; Hebbard } \\
\text { et al. 2008) }\end{array}$ \\
\hline Cadherin 24 & $\mathrm{CDH} 24$ & Nonsense mutation & $\begin{array}{l}\text { Acute myeloid } \\
\text { leukemia }\end{array}$ & NA & (Ley et al. 2008) \\
\hline \multirow{2}{*}{$\begin{array}{l}\text { LKC-protocadherin }= \\
\text { cadherin-related } \\
\text { protein } 24\end{array}$} & \multirow[t]{2}{*}{$P C D H 24=P C L K C$} & \multirow{2}{*}{ Reduced expression } & Colon & \multirow[t]{2}{*}{ NA } & \multirow[t]{2}{*}{ (Okazaki et al. 2002) } \\
\hline & & & $\begin{array}{l}\text { Liver } \\
\text { Kidney }\end{array}$ & & \\
\hline
\end{tabular}




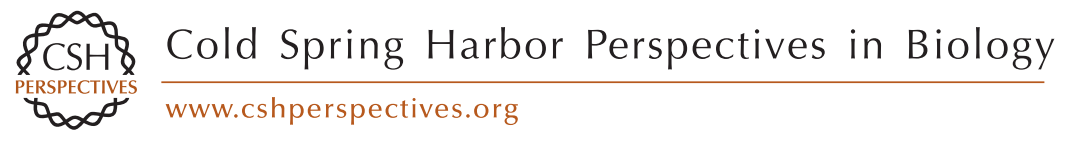

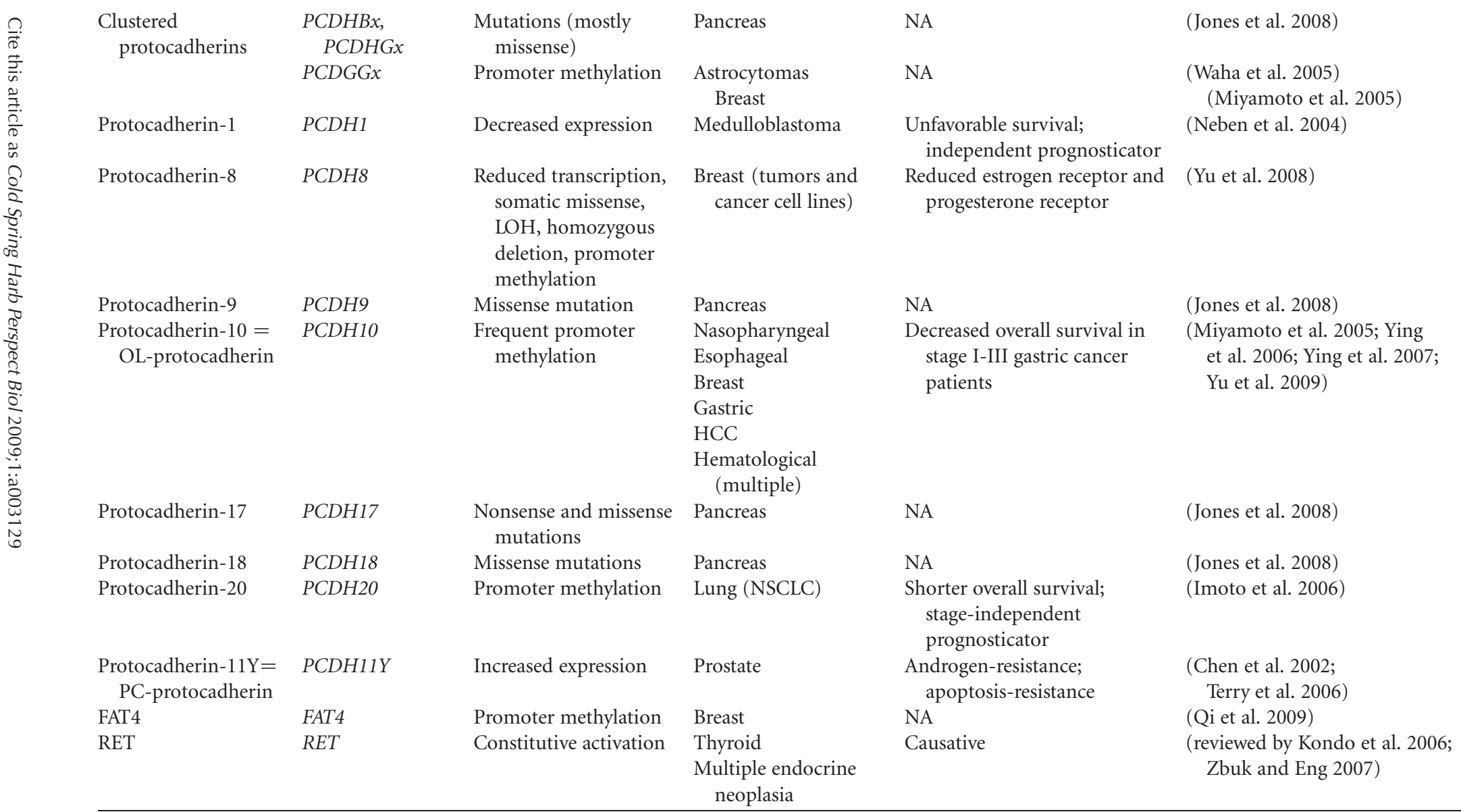

\footnotetext{
${ }^{1}$ BCC, basal cell carcinoma; CRC, colorectal carcinoma; DGC, diffuse gastric carcinoma; HCC, hepatocellular carcinoma; IBC, inflammatory breast carcinoma; ILC, invasive lobula carcinoma; NSCLC, nonsmall cell lung carcinoma; PDAC, pancreatic ductal adenocarcinoma; SCC, squamous cell carcinoma.

${ }^{2} \mathrm{NA}$ : not analyzed in this study.
} 


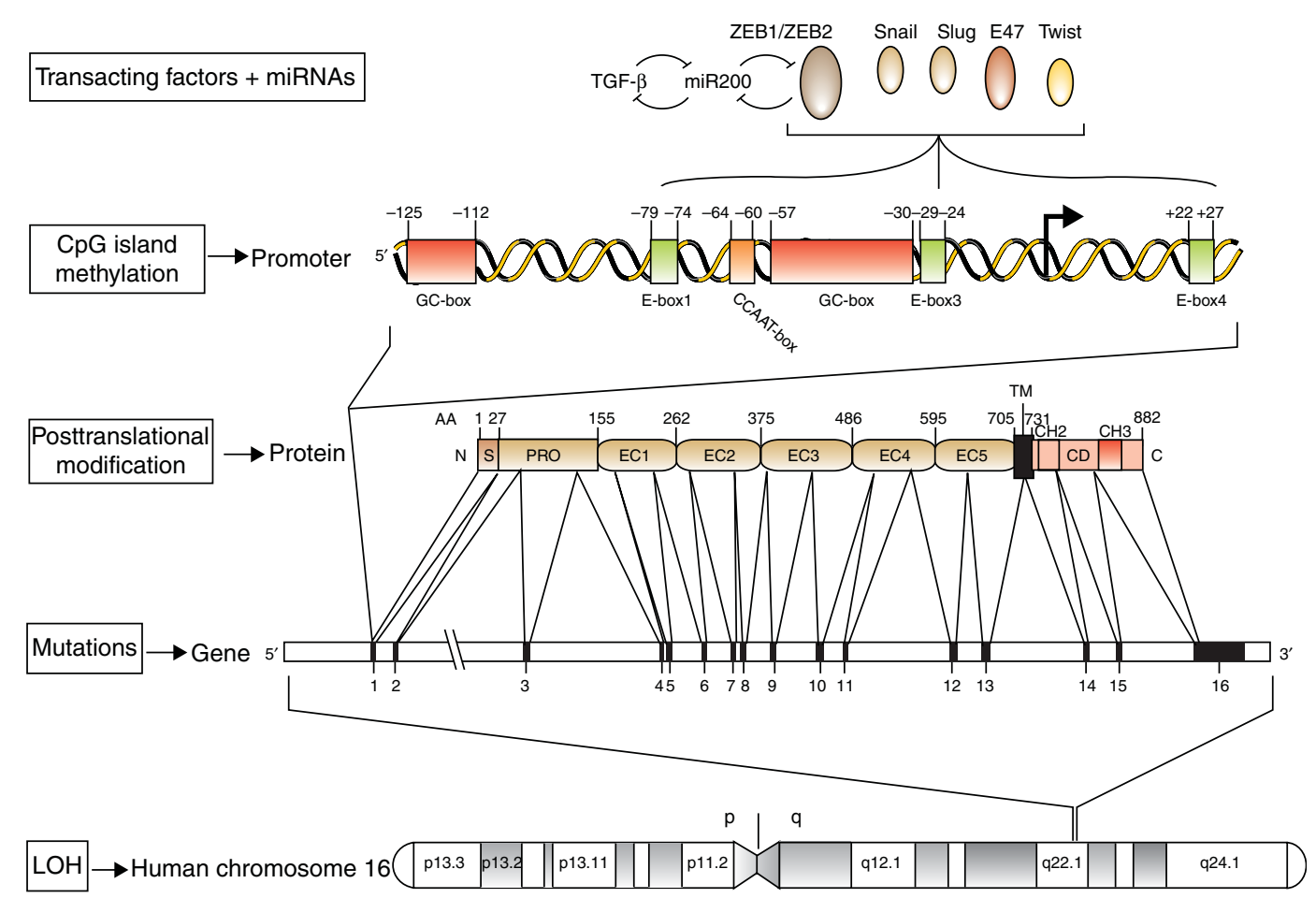

Figure 2. Various levels at which E-cadherin expression is regulated in human tumors (modified, with permission, from van Roy and Berx 2008). The E-cadherin gene CDH1 is on chromosome 16q22.1 (depicted at the bottom). This region frequently shows loss of heterozygosity (LOH) in different human carcinoma types. Specific inactivating mutations are scattered throughout the whole coding region and are particularly abundant in sporadic lobular breast cancer and diffuse gastric cancer. Germline mutations can also occur; they cause the hereditary diffuse gastric cancer syndrome. Furthermore, post-translational modifications, such as phosphorylation and glycosylation, and proteolytic processing can affect E-cadherin protein functionality. Epigenetic silencing has been associated with $\mathrm{CpG}$ methylation in the $C D H 1$ promoter region or with direct binding of specific transcriptional repressors to E-box sequences in this region. The

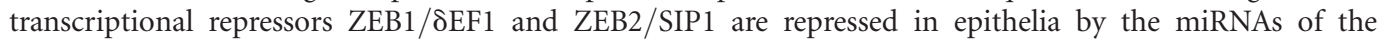
miR-200 family. In turn, the ZEB transcription factors down-regulate transcription of the miR-200 genes. Thus, a biphasic regulatory system controls the balance between the epithelial and mesenchymal status in response to incoming signals. TGF- $\beta$ in the tumor microenvironment can induce the expression of ZEB proteins, at least in part by down-regulating the miR-200 family members. This results in a self-enhancing loop that leads to epithelial dedifferentiation and invasion. See text for more details and references. AA, amino acid position; C, carboxy-terminal end; CD, cytoplasmic domain; EC, extracellular cadherin repeat; $\mathrm{N}$, amino-terminal end; $\mathrm{PRO}$, propeptide; $\mathrm{S}$, signal peptide; TM, transmembrane region. The arrows point to the transcriptional initiation start.

Strumane et al. 2004). LOH at 16q is frequent particularly in breast cancer, where it occurs in $\sim 50 \%$ of all ductal carcinomas (CletonJansen et al. 2001), and even more frequently in lobular breast cancer (Berx et al. 1996).

E-cadherin-inactivating mutations were first described in diffuse gastric cancer (Becker et al. 1993). In sporadic diffuse gastric cancer, somatic mutations preferentially cause skipping of exon 7 or 9, which results in in-frame deletions. Several truncations have also been reported in this histological subtype of tumors (Becker et al. 1994; Berx et al. 1998). Promoter hypermethylation, rather than $\mathrm{LOH}$, accounts here for biallelic $\mathrm{CDH} 1$ silencing (Machado et al. 2001). In contrast to these mutation 


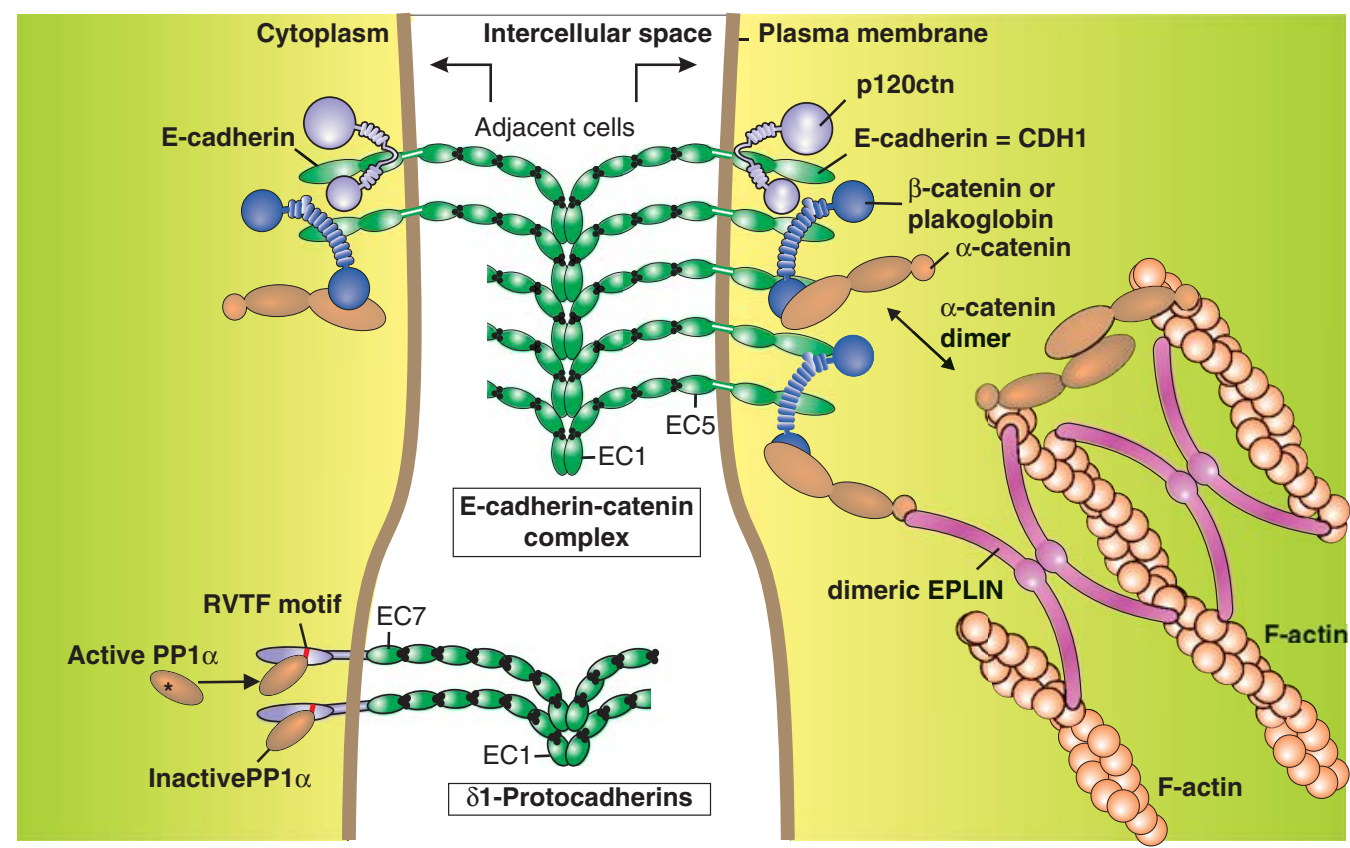

Figure 3. Schematic overview of the E-cadherin-catenin complex and of $\delta 1$-protocadherins at the junction between two adjacent cells (modified, with permission, from Redies et al. 2005; van Roy and Berx 2008). Top: The armadillo catenins p120ctn and $\beta$-catenin/plakoglobin bind to, respectively, membrane-proximal and carboxy-terminal halves of the cytoplasmic domain of E-cadherin. This increases junction strength and stability. As extensively described in the literature, both $\beta$-catenin and p120ctn also have cancer-related roles in the cytoplasm and in the nucleus. Monomeric $\alpha$-catenin binds to the E-cadherin cytoplasmic domain via $\beta$-catenin, whereas dimeric $\alpha$-catenin can bind and cross-link filamentous actin (F-actin). Moreover, dimeric EPLIN forms a link between the E-cadherin-catenin complex and F-actin. See text for more details and references. Bottom: The evidence for the depicted $\delta 1$-protocadherins structure is circumstantial, but the following features are typical: seven extracellular cadherin repeats (EC) instead of five and a completely different cytoplasmic domain with conserved motifs (CM). The CM3 or RVTF motif has been shown to interact with phosphatase PP1 $\alpha$, probably resulting in its inactivation (reviewed in Redies et al. 2005).

hotspots, E-cadherin inactivating mutations tend to be scattered along the $C D H 1$ gene in sporadic lobular breast carcinomas (Berx et al. 1995a; Berx et al. 1996). In this highly infiltrating cancer type, most $C D H 1$ mutations are outof-frame mutations predicted to yield secreted truncated E-cadherin fragments or no stable protein. E-cadherin expression is silenced because the mutations are accompanied by $\mathrm{CDH} 1$ promoter methylation or $\mathrm{LOH}$ (Berx et al. 1996; Berx et al. 1998; Droufakou et al. 2001). Missense mutations are infrequent in these two subtypes of cancer but frequent in monophasic synovial sarcomas (Saito et al. 2001). E-cadherin mutations are rare in carcinomas of bladder, colon, endometrium, lung, esophagus, ovary, and thyroid, and in intrahepatic cholangiocarcinoma (Risinger et al. 1994; Soares et al. 1997; Wijnhoven et al. 1999; Taddei et al. 2000; Endo et al. 2001; VecseySemjen et al. 2002).

Familial aggregation of gastric cancer is well known. These familial cancers can be classified histopathologically into hereditary diffuse gastric cancer (HDGC), familial diffuse gastric cancer (FDGC), and familial intestinal gastric cancer. The International Gastric Cancer Linkage Consortium (IGCLC) established criteria for identifying HDGC families based on the incidence and onset of diffuse gastric cancer (Caldas et al. 1999). Gastric cancers with high incidence and with an index case of 


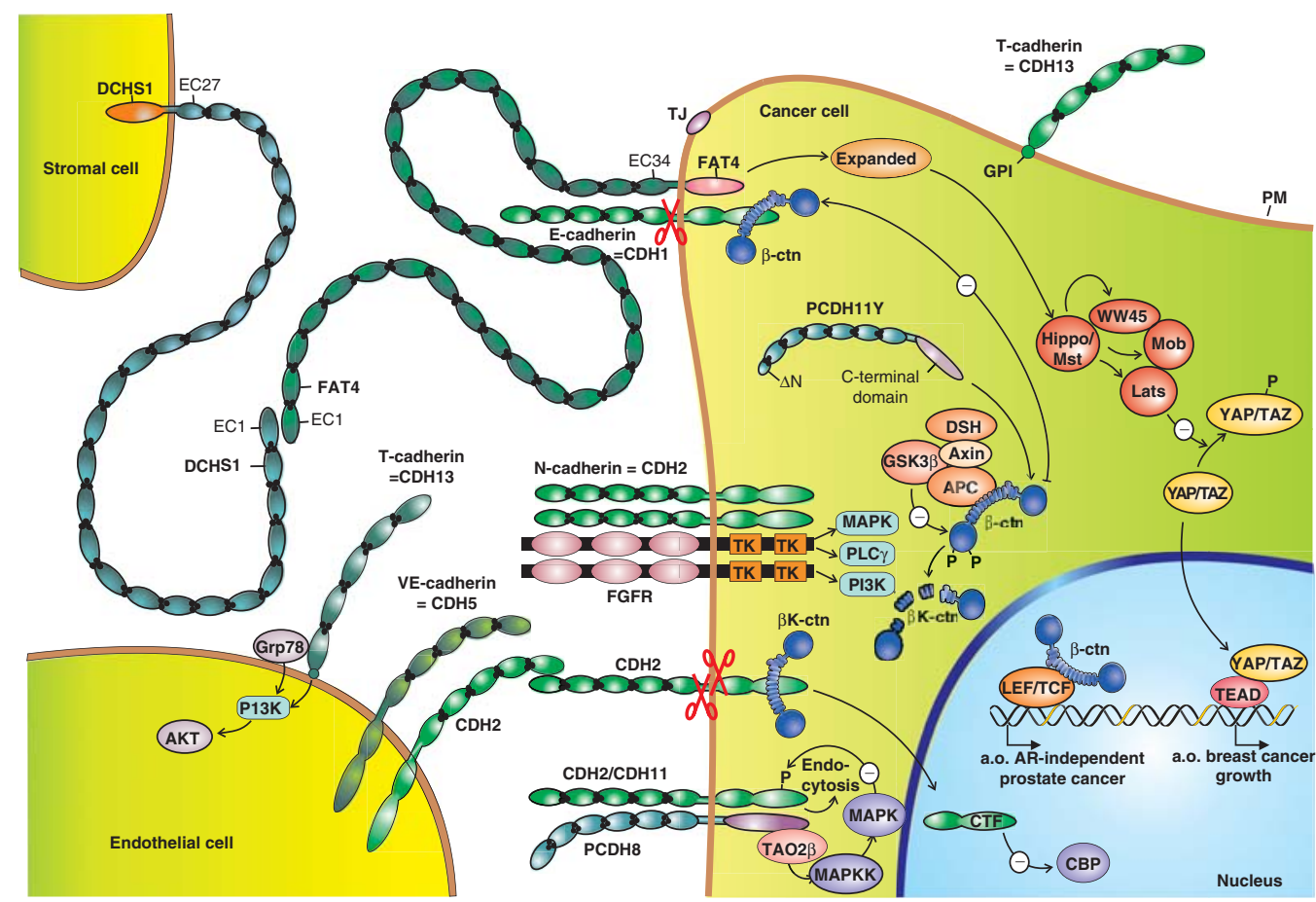

Figure 4. Selection of expression patterns and activities of members of the cadherin superfamily in cancer. Three cell types are partly depicted: a cancer cell, an endothelial cell, and another type of stromal cell. Protein domains in green are strongly homologous to those in the prototypic E-cadherin/CDH1. Domains in other colors deviate substantially in structure and function. Black dots represent $\mathrm{Ca}^{2+}$ ions. Arrows with minus sign symbols refer to direct or indirect inhibitory influences. Cadherins shown at the cancer cell surface are expressed at the apical membrane (T-cadherin/CDH13 above the tight junction, TJ), or at lateral membranes (E-cadherin/CDH1, $\mathrm{N}$-cadherin/CDH2, cadherin-11/CDH11). The latter three probably occur as cis-homodimers. CDH1 is frequently inactivated in cancer cells, whereas the "mesenchymal" cadherins CDH2 and CDH11 are often up-regulated. $\mathrm{CDH} 2$ can interact with fibroblast growth factor receptor (FGFR), potentiating its signaling through the enzymes MAPK, PLC $\gamma$, and PI3K. Cadherins are prone to proteolytic processing (scissors symbols), which releases either the ectodomain or a carboxy-terminal fragment (CTF). In the case of CDH2, this CTF has been shown to enter the nucleus and inhibit the CREB binding protein (CBP). On neural activation, $\mathrm{CDH} 2$ and $\mathrm{CDH} 11$ associate with protocadherin-8 (PCDH8 or Arcadlin), which results in activation of the MAPKKK TAO2 $\beta$, eventually leading to endocytosis of the cadherins. PCDH8 is often silenced in cancer cells, but it is unclear whether this is causally linked to up-regulation of mesenchymal cadherins. The transcriptional activity of $\beta$-catenin $(\beta$-ctn) in a nuclear complex with LEF/TCF, leads, amongst other effects, to androgen receptor (AR)-independent prostate cancer growth. This phenomenon is inhibited by sequestration of $\beta$-ctn by E-cadherin or by degradation of $\beta$-ctn after phosphorylation (-P) by GSK3 $\beta$. Degradation of $\beta$-ctn occurs in a cytoplasmic degradation complex with APC (adenomatous polyposis coli protein), Axin, and Disheveled (DSH). However, nuclear $\beta$-ctn-LEF/TCF activity is stimulated by an unknown mechanism by a cytoplasmic variant of protocadherin-11Y (PCDH11Y) lacking a signal peptide because of a truncated aminoterminus $(\Delta \mathrm{N})$. Tumor-associated endothelial cells express VE-cadherin/ $\mathrm{CDH} 5, \mathrm{CDH} 2$, and T-cadherin/CDH13. The latter is linked to the PM via a glycosylphosphatidylinositol (GPI) anchor and signals via secreted Grp78/BiP to an anti-apoptotic PI3K-AKT pathway. Dachsous-1 (DCHS1) and FAT4 are both huge cadherin-related proteins, interacting with each other in heterophilic (different protein types) and heterotypic (different cell types) ways. Silencing of human FAT4 is seen in breast cancer and its activation is linked in an unresolved way to the Hippo-YAP pathway, which controls organ size in Drosophila and is affected in several human cancers. See text for details and references. (a.o.) Amongst others; (EC) extracellular cadherin repeat; (PM) plasma membrane; (TK) tyrosine kinase domain. 
diffuse gastric cancer but not fulfilling the IGCLC criteria for HDGC are classified as FDGC (Oliveira et al. 2006).

Germline mutations in the E-cadherin gene were first described in 1998 by Guilford et al. (1998), who identified CDH1-inactivating mutations in three Maori families with early-onset diffuse gastric cancer. Since then, 68 families carrying germline $\mathrm{CDH} 1$ mutations have been identified worldwide (Carneiro et al. 2008). CDH1 mutations were found in $30.5 \%$ of HDGC families and $13.8 \%$ of FDGC families (reviewed in Oliveira et al. 2006). These mutations resemble sporadic mutations in that most of them are predicted to cause premature stop codons caused by nonsense, splice-site, or frameshift mutations. Only some of them were missense mutations (Pereira et al. 2006). Some of these E-cadherin missense mutants are subjected to ER quality control followed by ER-associated degradation (Simoes-Correia et al. 2008). Germline mutations are scattered along the entire gene.

Multiple cases of lobular breast cancer (including mixed ductal and lobular histology) have been reported in families with HDGC (Caldas et al. 1999; Pharoah et al. 2001; Brooks-Wilson et al. 2004; Suriano et al. 2005). The estimated cumulative lifetime risk of breast cancer in women from HDGC families with germline CDH1 mutations is $39 \%$ (Pharoah et al. 2001). Remarkably, CDH1 germline mutations can be associated with invasive lobular breast cancer in the absence of diffuse gastric cancer (Masciari et al. 2007). Most of these hereditary tumors are E-cadherinnegative, pointing to a double inactivating mechanism.

Predisposition to diffuse gastric cancer and lobular cancer in patients carrying germline mutations in the E-cadherin gene identify Ecadherin as a tumor suppressor (Dunbier and Guilford 2001). An in vivo role of E-cadherin in cancer progression was supported by demonstrating that expression of a dominant-negative E-cadherin mutant in a mouse pancreatic $\beta$-cell tumor model accelerated conversion of adenomas into carcinomas (Perl et al. 1998). In contrast, in mouse models specific loss of E-cadherin in the skin and the mammary gland is not sufficient for tumorigenesis (Boussadia et al. 2002; Tinkle et al. 2004; Tunggal et al. 2005). This ablation caused extensive cell death in the mammary gland, which indicates that the frequent loss of E-cadherin in epithelial cancers, including breast carcinomas, must be accompanied by oncogenic antideath mechanisms. This was shown by combining a floxed Cdh1 gene with the K14-Cre gene, which is expressed at low, stochastic levels in mammary epithelium (Derksen et al. 2006). No abnormalities were seen in these mice, but combined loss of E-cadherin and p53 resulted in accelerated development of malignant mammary carcinomas resembling human infiltrative lobular carcinomas. Ablating both tumor suppressors induced more metastatic spreading, anoikis resistance, and vascularization than loss of p53 alone.

\section{Epigenetic Silencing of the E-cadherin Locus in Cancer}

Promoter hypermethylation is an important epigenetic event associated with loss of E-cadherin gene expression during cancer progression (Fig. 2; Table 1). A large CpG island in the $5^{\prime}$ proximal promoter region of the E-cadherin gene (Berx et al. 1995b) shows aberrant DNA methylation in at least eight human carcinoma types and correlates with reduced E-cadherin protein expression (Graff et al. 1995; Yoshiura et al. 1995; Chang et al. 2002; Kanazawa et al. 2002). In cancer cell lines, promoter methylation of the E-cadherin gene is heterogeneous, dynamic, unstable, and associated with allele to allele variability (Graff et al. 1995; Graff et al. 1998; Graff et al. 2000). This is compatible with heterogeneous loss of E-cadherin protein expression, which might be influenced by the tumor microenvironment. CpG island methylation in the $\mathrm{CDH} 1$ gene seemingly increases during malignant progression of breast and hepatocellular carcinomas (Kanai et al. 2000; Nass et al. 2000).

Causal involvement of hypermethylation in E-cadherin repression is supported by the reactivation of functional E-cadherin in 
certain cancer cell lines on treatment with the demethylating agent 5-aza-2'-deoxycytidine (5AzaC) (Graff et al. 1995; Yoshiura et al. 1995; Nam et al. 2004). Binding of the methyl-CpG binding proteins $\mathrm{MeCP} 2$ and MBP2 to the methylated CPG island of the repressed E-cadherin promoter results in recruitment of HDACs to the promoter area, leading to histone-3 (H3) deacetylation, which is essential for suppressing the methylated E-cadherin gene (Koizume et al. 2002). Interestingly, the methylated $\mathrm{CDH1}$ promoter status in breast cancer cell lines seems to be part of a general transcriptional program that conforms with EMT and increased invasiveness, but diverges from the specific consequence of E-cadherin mutational inactivation (Lombaerts et al. 2006).

\section{Transcriptional Silencing, EMT, and Cancer}

Different repressors of E-cadherin transcription have been associated with the progression of multiple cancer types (Fig. 2). Increased Snail expression, common in ductal breast carcinomas, is strongly associated with reduced E-cadherin gene expression (Cheng et al. 2001). High-grade breast tumors and lymphnode positive tumors consistently show strong Snail expression (Blanco et al. 2002). A new role for Snail in tumor recurrence has been inferred from a reversible HER-2/neu-induced breast cancer mouse model (Moody et al. 2005). Also, abnormal expression of Slug has been associated with disease aggressiveness in metastatic ovarian and breast carcinoma (Elloul et al. 2005). Twist, another EMTregulating transcription factor, is involved in breast tumor metastasis (Yang et al. 2004), and its expression rises as nodal involvement increases (Martin et al. 2005). Strong expression of SIP1/ZEB2, which is associated with loss of E-cadherin expression, was reported in gastric cancer of the intestinal type, but Snail does not seem to be involved in these tumors (Rosivatz et al. 2002). In contrast, Snail is up-regulated in diffuse gastric cancer, a tumor subtype frequently affected by E-cadherin inactivating mutations (Rosivatz et al. 2002). The transcription factor deltaEF1/ZEB1 seems to be downstream of Snail expression (Guaita et al. 2002). Knock-down of deltaEF1/ZEB1 in dedifferentiated human epithelial colon and breast cancer cell lines results in re-expression of E-cadherin and other epithelial differentiation markers (Eger et al. 2005; Spaderna et al. 2006; Spaderna et al. 2008). Though extensive data show that expression of E-cadherin repressors is inversely correlated with expression of E-cadherin, these results should be interpreted carefully because many data are based on RT-PCR and on the use of antibodies with poorly defined specificity.

Recently, induction of expression of E-cadherin transcriptional repressors has been inversely linked with the expression status of the von Hippel-Lindeau (VHL) tumor suppressor (reviewed in Russell and Ohh 2007). Loss of VHL is an early, requisite step in the pathogenesis of clear-cell renal cell carcinoma (CC-RCC) (Lubensky et al. 1996). Activation of $\mathrm{HIF} \alpha$ proteins in cells devoid of VHL, including CC-RCC cells, induces transactivation of several E-cadherin repressors, e.g., SIP1/ZEB2 and Snail, which contributes to the particularly malignant character of this tumor type (Esteban et al. 2006; Krishnamachary et al. 2006; Evans et al. 2007).

Regulatory cross-modulation exists between different E-cadherin-repressing transcription factors and specific microRNAs (Fig. 2). Members of the miR-200 family and miR-205 directly target ZEB1/deltaEF1 and ZEB2/SIP1 mRNAs, thereby repressing ZEB1 and ZEB2 protein translation and hence increasing E-cadherin expression (Christoffersen et al. 2007; Hurteau et al. 2007; Burk et al. 2008; Gregory et al. 2008; Korpal et al. 2008; Park et al. 2008). Expression analysis of miRNAs in normal human tissues showed that the miRNAs targeting ZEB family members are particularly abundant in epithelial tissues (Liang et al. 2007). Experimental up-regulation of miR-200c in dedifferentiated metastatic breast cancer cells suppresses their invasive behavior (Burk et al. 2008). Alternatively, ZEB1/ deltaEF1 represses transcription of miR-200 family members by binding to E-box elements 
in the promoter regions of polycistronic primary miRNAs encoding these miRNAs (Bracken et al. 2008; Burk et al. 2008). These different miRNAs are repressed both by TGF- $\beta$ and by overexpression of the tyrosine phosphatase Pez, which results in EMT with loss of E-cadherin expression (Gregory et al. 2008). In turn, the EMT activator TGF- $\beta 2$ is also downregulated by these miRNAs, indicating that ZEB1/deltaEF1 induces a microRNA-mediated feed-forward loop, which can re-enforce EMT (Lopez and Hanahan 2002; Burk et al. 2008).

Increasing evidence shows that diverse solid tumors are hierarchically organized and sustained by a distinct subpopulation of cancer stem cells (CSCs). For breast cancer, Al-Haij et al. (2003) described a CD $44^{\text {high }} / \mathrm{CD} 24^{\text {low }}$ cell population that had greater tumor-initiating capacity. Surprisingly, normal mammary epithelial cells could be induced to adopt the stem-cell like $\mathrm{CD} 44^{\text {high }} / \mathrm{CD} 24^{\text {low }}$ expression profile when exposed to TGF- $\beta$ or on conditional overexpression of the EMT inducing transcription factor Snail or Twist. The resulting population displayed mesenchymal and stem cell markers and acquired stem-cell like properties, including enhanced growth in mammosphere cultures and increased formation of soft agar colonies (Mani et al. 2008). Moreover, activation of the Ras/MAPK signaling pathway in primary human mammary epithelial cells appeared to be crucial for facilitating the emergence of $\mathrm{CD} 44^{\text {high }} / \mathrm{CD} 24^{\text {low }}$ cells (Morel et al. 2008).

\section{Endocytosis and Proteolytic Processing of E-cadherin in Cancer}

Multiple mechanisms other than genetic and epigenetic silencing of E-cadherin could serve as alternative ways for disturbing or inhibiting normal E-cadherin function under pathological conditions. As reviewed (van Roy and Berx 2008), E-cadherin is removed from the plasma membrane by endocytosis and recycled to sites of new cell-cell contacts. Abnormal activation of proto-oncogenes, such as c-Met, Src, and EGFR, results in increased phosphorylation of tyrosine residues in the cytoplasmic domain of E-cadherin, which leads to recruitment of the E3-ubiquitin ligase Hakai and subsequently mediates internalization and ubiquitin-dependent degradation of E-cadherin (Fujita et al. 2002; Shen et al. 2008).

Because p120ctn participates in stabilizing the cadherin-catenin complex, many cancer types are characterized by loss or dislocalization of p120ctn (reviewed in van Hengel and van Roy 2007). We recently showed that p120ctn interacts with hNanos1, the human ortholog of the Drosophila zinc-finger protein, Nanos (Strumane et al. 2006). Transcription of hNanos 1 mRNA is often suppressed on E-cadherin expression. Conditional expression of hNanos1 in human colon DLD1 cancer cells induces cytoplasmic translocation of p120ctn, up-regulates expression of membrane type 1-matrix metalloproteinase (MT1-MMP) at the mRNA and protein levels, and increases migratory and invasive abilities (Strumane et al. 2006; Bonnomet et al. 2008).

Moreover, matrix metalloproteinases, including stromelysin-1 (MMP3), matrilysin (MMP7), MMP9, and MT1-MMP (MMP14), cleave the E-cadherin ectodomain near the plasma membrane (Fig. 4) (Lochter et al. 1997; Davies et al. 2001; Noë et al. 2001; Covington et al. 2006; Symowicz et al. 2007). Several other proteases, such as the serine protease kallikrein 6 (Klk6), are up-regulated in human squamous skin carcinomas. Ectopic expression of Klk6 in keratinocytes induces E-cadherin ectodomain shedding in parallel with increased levels of mature ADAM10 proteinase (Klucky et al. 2007). Pancreatic adenocarcinomas often overexpress kallikrein-7, which can also generate soluble E-cadherin fragments that may function as pseudoligands to block normal E-cadherin interactions and promote invasion (Johnson et al. 2007). In epithelial ovarian carcinomas, the tumor cells maintain direct contact with ascites, which accumulates high concentrations of the solubilized E-cadherin ectodomain, and thereby promotes disruption of cell-cell junctions and metastatic dissemination (Symowicz et al. 2007). ADAM15, which is associated with progression of breast and prostate cancers, also 
generates a soluble E-cadherin ectodomain (Najy et al. 2008). This E-cadherin fragment appeared to stabilize heterodimerization of the HER2 (ErbB2) receptor tyrosine kinase with HER3, thus leading to Erk signaling, which stimulates both cell proliferation and migration.

The ectodomain of E-cadherin is also a substrate of secreted cathepsins B, L, and S, but not cathepsin C (Gocheva et al. 2006). This correlates with impaired malignant invasion on ablation of any of these three cathepsins in the mouse pancreatic islet cell carcinogenesis model, RIP1-Tag2, whereas tissue-specific cathepsin C knockout had no effect on either tumor formation or progression. Cathepsins are often secreted by various cells in the tumor microenvironment (Mohamed and Sloane 2006).

\section{MESENCHYMAL CADHERINS AND P-CADHERIN}

Loss of expression of E-cadherin (CDH1), P-cadherin (CDH3), or both in invasive tumor cell lines and malignant tissues from breast cancers, prostate cancers, and melanomas is often associated with induced expression of the mesenchymal $\mathrm{N}$-cadherin ( $\mathrm{CDH} 2)$, generally referred to as cadherin switching (reviewed by Tomita et al. 2000; Hazan et al. 2004; Wheelock et al. 2008) (Table 1). E-cadherin down-regulation together with de novo $\mathrm{N}$-cadherin expression is also observed in a Rip1-Tag2 mouse tumor model, in which tumor progression is accelerated by overexpression of IGF1R in the pancreatic $\beta$-cells (Lopez and Hanahan 2002). Normally, cadherin-11 (OB-cadherin or CDH11) (Fig. 1) is constitutively expressed in stromal and osteoblastic cells. Its misexpression in carcinoma cell lines and malignant breast and prostate tissues coincides with greater invasiveness and poor prognosis (Table 1) (Pishvaian et al. 1999; Bussemakers et al. 2000; Tomita et al. 2000). Manipulation of cadherin-11 expression in experimental metastasis models for breast and prostate cancers suggests that it promotes homing and migration to bone (Chu et al. 2008; Tamura et al. 2008). In human prostate cancers, cadherin-11 expression increases with progression from primary to metastatic disease in lymph nodes and particularly in bone (Chu et al. 2008).

E-cadherin repressors, such as Snail, ZEB2/ SIP1, and Slug, can induce N-cadherin and cadherin-11 expression during EMT, suggesting that this cadherin switch is part of a transcriptional reprogramming of dedifferentiating epithelial cells (Cano et al. 2000; Vandewalle et al. 2005; Sarrio et al. 2008). Overexpression of $\mathrm{N}$-cadherin in epithelial breast tumor cells induces a scattered morphology even when E-cadherin is present, and increases their motility, invasiveness, and metastatic capacity (Nieman et al. 1999; Hazan et al. 2000). This enhanced malignancy can be partly explained: Tumor cells, which express $\mathrm{N}$-cadherin, are more able to interact with $\mathrm{N}$-cadherin-positive tissues, including stroma and endothelium, potentially promoting their access to the vasculature and penetration and survival in secondary organs (Fig. 4) (Hazan et al. 1997; Hazan et al. 2000).

In contrast to the malignant contribution of $\mathrm{N}$-cadherin overexpression in breast tumor cell models, mammary gland tumors arising in a bi-transgenic mouse model overexpressing both $\mathrm{N}$-cadherin and ErbB2/HER-2/neu in a tissue-specific manner are not pathologically different from the tumors in single ErbB2/ HER-2/neu transgenic mice (Knudsen et al. 2005). However, coexpression of N-cadherin with polyomavirus middle- $T$ antigen in the mammary epithelium produces breast cancers with greater potential for metastasis to the lung (Hulit et al. 2007). N-cadherin did not enhance tumor onset but affected tumor progression by potentiating oncogenic ERK signaling, leading to MMP-9 up-regulation. These studies suggest that the effects of cadherin switching could occur late in tumor progression and that the impact of abnormal cadherin expression can depend on the cellular context. The concerted action of additional events, such as overexpression of $\mathrm{FGF}(\mathrm{R})$, loss of E-cadherin, or up-regulation of MMPs might be required together with $\mathrm{N}$-cadherin up-regulation to promote mammary tumor invasion and metastasis in vivo. In breast cancer cells, 
$\mathrm{N}$-cadherin and FGF2 synergistically increase migration, invasion, and secretion of extracellular proteases (Hazan et al. 2004).

Mechanistically, $\mathrm{N}$-cadherin is believed to functionally interact with the FGF receptor, causing sustained downstream signaling by phospholipase $\mathrm{C} \gamma, \mathrm{PI}(3) \mathrm{K}$, and MAPK-ERK to promote cell survival, migration, and invasion (Fig. 4) (Suyama et al. 2002). Shedding of $\mathrm{N}$-cadherin by proteases might stimulate FGFR signaling in neighboring cells. Furthermore, presenilin 1 (PS1)/ $\gamma$-secretase cleaves $\mathrm{N}$-cadherin in the cytoplasmic part to release a free carboxy-terminal $35-\mathrm{kDa}$ fragment, which translocates to the nucleus and binds the transcriptional coactivator CBP (CREB binding protein) (Fig. 4) (Marambaud et al. 2003). This targets CBP for degradation and represses $\mathrm{CBP} / \mathrm{CREB}$-mediated transcription.

P-cadherin (CDH3) is expressed abnormally in basal-like breast carcinomas and in most pancreatic ductal adenocarcinomas (Table 1) (Paredes et al. 2005; Taniuchi et al. 2005). The p120-catenin binding juxtamembrane domain (JMD) of P-cadherin could be crucial for the enhancement of invasion and migration caused by P-cadherin overexpression in these cancers (Paredes et al. 2004). The underlying mechanism is unclear, but small sequence differences between the JMDs of E-cadherin and P-cadherin might result in differential binding of interacting proteins and modulation of p120ctn functionality in case of association with P-cadherin (Paredes et al. 2007). In melanoma cell lines P-cadherin can counteract invasion (Van Marck et al. 2005), which appears to agree with the shift in human melanoma from active, membranous to cytoplasmic P-cadherin (Sanders et al. 1999).

\section{VE-CADHERIN (CADHERIN-5) AND OTHER TYPE-II CADHERINS}

The endothelial specific expression of VE-cadherin (cadherin-5) plays a key role in regulating vascular morphology and stability (Fig. 4) (Dejana 2004; reviewed by Cavallaro et al. 2006). Microarray studies revealed that VE-cadherin is overexpressed in aggressive human cutaneous and uveal melanoma cells, but not in nonaggressive or poorly aggressive melanoma (Table 1) (Bittner et al. 2000). On the other hand, formation of patterned networks of matrix-rich tubular structures in three-dimensional culture is characteristic of highly aggressive but not poorly aggressive melanoma cells (Maniotis et al. 1999). This vascular mimicry is clinically significant and increases the risk of metastatic disease (Warso et al. 2001). Aggressive melanoma cells in which VE-cadherin was repressed could not form vasculogenic-like networks (Hendrix et al. 2001), suggesting that tumor-associated misexpression of VE-cadherin (observed in melanoma cells) is instrumental in mimicking endothelial cells to form vasculogenic networks. Recently, VE-cadherin was found to be targeted to proteasome-mediated degradation by a transmembrane ubiquitin ligase of the Kaposi's sarcoma-associated herpesvirus (Mansouri et al. 2008). This resulted in a reduction of the steady-state levels of interacting catenins and in rearrangement of the actin cytoskeleton. This reprogramming and differentiation of endothelial cells accompanies loss of endothelial barrier function and vascular leakage, which could be relevant during Kaposi's sarcoma tumor formation (Mansouri et al. 2008).

Antiangiogenic tumor therapy is lately receiving much attention in the form of anti-VEGF therapy (Loges et al. 2008). Also VE-cadherin has become a target for inhibition of pathological angiogenesis. Monoclonal antibodies directed against VE-cadherin could inhibit angiogenesis and reduce tumor growth of experimental hemangiomas and gliomas (Corada et al. 2002; Cavallaro et al. 2006). Specificity for angiogenic tumor vasculature was further enhanced by targeting a VEcadherin epitope that is at least partly engaged in trans-dimer formation, and thus is masked on established vessels (May et al. 2005). This therapy is antiangiogenic during neovascularization because de novo adherens junction formation is inhibited. The potential value of anti-VE-cadherin therapy was further shown by using a cyclic peptide directed against VEcadherin to inhibit oxygen-induced retinal 
neovascularization (Navaratna et al. 2008). Regarding angiogenesis, it is worth mentioning that endothelial cells also express $\mathrm{N}$-cadherin, R-cadherin (CDH4), and T-cadherin (cadherin13; see the following discussion). N-cadherin is involved in recruitment (or binding) of pericytes, which stabilizes blood vessel formation (Cavallaro et al. 2006). The functions of $\mathrm{T}$-cadherin and R-cadherin in endothelial cells are unclear. In gastrointestinal cancer, the $\mathrm{CDH} 4$ promoter is often methylated early in tumor progression, indicating that R-cadherin might be a tumor suppressor (Miotto et al. 2004).

Recently, the cytogenetically normal genome of a typical acute myeloid leukemia sample was fully sequenced and compared with the genome of normal skin cells of the same patient (Ley et al. 2008). Only ten genes with acquired mutations were identified, including a nonsense mutation in the ectodomain of cadherin-24 (CDH24). This type-II cadherin (Fig. 1) (Hulpiau and van Roy 2009) has received little attention. It is widely expressed in human tissues, binds p120 and $\beta$-catenin, and can mediate strong cell-cell adhesion (Katafiasz et al. 2003).

\section{CADHERIN-13 (T-CADHERIN)}

Cadherin-13 (CDH13), also called T(runcated)or $\mathrm{H}$ (eart)-cadherin, is most peculiar. It is the only known cadherin that is membraneanchored via a glycosylphosphatidylinositol (GPI) anchor instead of transmembrane domains (Figs. 1 and 4). This explains its unusual location at apical instead of basolateral membranes in polarized epithelial cells (Ranscht and Dours-Zimmermann 1991). Nevertheless, the extracellular domain of CDH13 shows significant homology with the ectodomain of classical cadherins (Hulpiau and van Roy 2009), and its binding is indeed homophilic though relatively weak because of structural peculiarities (Vestal and Ranscht 1992; Dames et al. 2008). This binding weakness suggests that $\mathrm{CDH} 13$ functions mainly in signaling.

The human $\mathrm{CDH} 13$ gene is located on chromosome 16q24, and because it is frequently silenced in many different cancers, it has long been considered to be a tumor suppressor (Table 1) (Lee 1996; reviewed by Takeuchi and Ohtsuki 2001). Also, CDH13 LOH is frequently observed in major cancer types. In several of these studies, treatment of tumor cell lines with a demethylating agent or a histone deacetylase inhibitor reactivated $\mathrm{CDH} 13$ expression. Methylation of the $\mathrm{CDH13}$ promoter was associated with recurrence of nonsmall-cell lung cancers after surgery (Brock et al. 2008). A genome-wide study of association of single-nucleotide polymorphisms (SNPs) with prostate cancer revealed four candidate susceptibility genes, including $\mathrm{CDH} 13$ (Thomas et al. 2008). Cdh13 expression was up-regulated in castrated mice but was down-regulated following androgen replacement, which is in line with androgen-responsive elements in its promoter region (Wang et al. 2007). Exogenous expression of CDH13 in DU145, a cell line derived from a prostate cancer metastasis, reduced tumorigenicity, whereas knockdown of $\mathrm{CDH} 13$ transcripts in BPH1, derived from benign prostate hyperplasia, facilitated tumorigenesis (Wang et al. 2007).

Other experiments point to several growth inhibitory effects of CDH13 (Lee 1996; Huang et al. 2003; Mukoyama et al. 2005; Yan et al. 2008), but the underlying mechanism is unclear. Overexpression of $\mathrm{CDH} 13$ in carcinoma or glioma cells causes $\mathrm{G} 2 / \mathrm{M}$ cell cycle arrest (Huang et al. 2003). In the glioma study, arrest depended on expression of the CDK inhibitor $\mathrm{p} 21^{\mathrm{CIP} 1}$ but not on expression of p53. Another study reported that $\mathrm{CDH} 13$ interferes with c-Jun oncogenic activity (Chan et al. 2008). Moreover, in vitro invasiveness of breast cancer cells was inhibited by exogenous expression of CDH13 (Lee et al. 1998). However, exceptions do occur: One highly invasive hepatoma cell line autonomously produces high levels of $\mathrm{CDH} 13$, and knockdown of this expression reduced invasion and migration activity (Riou et al. 2006).

The recently reported $C d h 13$ knockout mouse did not show spontaneous tumors or other overt phenotypic abnormality, but crossing it with the MMTV-polyomavirus-middle-T 
(MMTV-PyV-MT) transgenic mouse resulted in offspring with $\mathrm{CDH} 13$-deficient mammary tumors that were growth restricted and less vascularized (Hebbard et al. 2008). Nevertheless, these $\mathrm{CDH} 3$-deficient tumors had greater metastatic potential than wild-type MMTV-PyVMT tumors, which might be explained by hypoxia-driven EMT (see also previous discussion). The discrepancy of these in vivo findings with the proposed tumor suppressor function of $\mathrm{CDH} 13$ could be partly because of the contribution of tumor vasculature.

Indeed, $\mathrm{CDH} 13$ was found to be induced in microvessels associated with tumors and metastases, whereas in normal tissues it was expressed only in larger vessels (Wyder et al. 2000). In hepatocellular carcinoma (HCC), $\mathrm{CDH} 13$ is silenced in the cancer cells but overexpressed in the intratumoral endothelial cells (Adachi et al. 2006; Riou et al. 2006; Chan et al. 2008). In a two-chamber system, angiogenic factor FGF-2 derived from HCC cells induced CDH13 expression in sinusoidal endothelial cells (Adachi et al. 2006). Overexpression of $\mathrm{CDH} 13$ in a human microvascular endothelial cell line stimulated invasion of these nontumoral cells into multicellular spheroids of undifferentiated melanoma cells lacking $\mathrm{CDH} 13$ expression (Ghosh et al. 2007). Overexpression and homophilic ligation of $\mathrm{CDH} 13$ in endothelial cells stimulates their proliferation and migration, enhances their protection against oxidative stress, and stimulates angiogenesis under pathological conditions, apparently by potentiating factors such as VEGF (Philippova et al. 2006). Growth of CDH13-expressing MMTV-PyVMT tumors transplanted in mammary fat pads of Cdh13-null recipient mice was slower than in wild-type mice, consolidating the nonautonomous effect of $\mathrm{CDH} 13$ on tumor growth (Hebbard et al. 2008).

How does $\mathrm{CDH} 13$ act as a stromal factor favoring tumor growth whereas the tumor cells themselves tend to silence its expression? On homophilic ligation of $\mathrm{CDH} 13$ on surfaces of endothelial cells it becomes linked to different interacting proteins, including Grp78/BiP (Philippova et al. 2008). The latter is normally retained within the ER but becomes surface exposed under pathological conditions. Endothelial cell survival is apparently promoted by surface exposed Grp78 via the phosphatidylinositol 3-kinase and Akt kinase pathway (Fig. 4). Another interesting $\mathrm{CDH} 13$ partner in endothelial cells is $\alpha_{v} \beta_{3}$ integrin. $\mathrm{CDH} 13$ colocalizes with this integrin mostly at the leading edge of migrating cells, which agrees with a proangiogenic $\mathrm{CDH} 13$ effect (Philippova et al. 2008).

CDH13 was also identified as a "third adiponectin receptor" (reviewed by Takeuchi et al. 2007). Adiponectin, secreted by adipocytes, is a hormone with insulin-sensitizing effects. In serum it exists as trimers, hexamers, or high molecular weight oligomers. $\mathrm{CDH} 13$ probably serves as coreceptor with the more classic adiponectin-receptor-1 and -2 for binding hexameric and larger adiponectin forms (Hug et al. 2004). The possible relevance of this coreceptor function of $\mathrm{CDH} 13$ to cancer is supported by evidence from the MMTV-PyVMT mammary tumor system (Hebbard et al. 2008). When $C d h 13$ was ablated, adiponectin was no longer associated with the tumor vasculature and its serum levels increased. As adiponectin can sequester various growth factors, its $\mathrm{CDH} 13$-dependent accumulation in a tumoral microenvironment may favor both tumorassociated neoangiogenesis and tumor growth.

\section{PROTOCADHERINS AND CANCER}

As recently reviewed (Hulpiau and van Roy 2009), protocadherins differ in many aspects from classic cadherins (Figs. 1 and 3). They can be subdivided into clustered and nonclustered protocadherins, reflecting the localization of their genes in vertebrate genomes. Transcripts of clustered protocadherins are composed of one of many variable exons combined with a few constant exons. Three subfamilies of clustered protocadherins are discerned in mammals: $\alpha-, \beta$-, and $\gamma$-protocadherins. Evidence for the involvement of clustered protocadherins in cancer is limited. In a global genomic analysis of pancreatic cancers, more than 23,000 pancreatic cancer-derived transcripts were sequenced (Jones et al. 2008) 
(Table 1). This revealed cancer-associated somatic missense mutations in some members of the clustered protocadherin subfamilies, but their functional relevance remains unclear. Other studies pointed at the involvement of methylation of the PCDHGA11 or PCDHGB6 promoter region in the development of astrocytomas or breast cancer (Miyamoto et al. 2005; Waha et al. 2005).

Considerably more information is available about the nonclustered protocadherins, a family comprising 10 members in man and other mammals (Hulpiau and van Roy 2009). In the same large-scale analysis of pancreatic cancers (Jones et al. 2008), missense mutations were found in protocadherin-9, -17 , and -18 . Expression of protocadherin-1 (PCDH1) in medulloblastoma patients predicted survival (Table 1) (Neben et al. 2004).

In breast cancer, protocadherin-8 (PCDH8) was proposed as a candidate tumor suppressor (Table 1) (Yu et al. 2008), as several somatic missense mutations affecting the ectodomain or a conserved motif in the cytoplasmic domain were found in tumor samples and cell lines ( $\mathrm{Yu}$ et al. 2008). Proliferation and migration of breast cancer cell lines was inhibited by forced expression of wild type PCDH8 but not by two of the ectodomain missense mutations. Moreover, the E146K mutation, assumed to affect a calcium-coordinating amino acid in PCDH8, conferred a transformed phenotype on "normal" MCF10A cells (Yu et al. 2008). Contrary to common descriptions, PCDH8 is not the homolog but the close paralog of the paraxial protocadherin (PAPC) of Xenopus laevis (Hulpiau and van Roy 2009). So one should be careful when interpreting PCDH8 functions based on the numerous reported findings on Xenopus PAPC (e.g., Unterseher et al. 2004). Interestingly, neural stimulation induces a short isoform of Arcadlin (= rat Pcdh8) in hippocampal synapses, where it associates with $\mathrm{N}$-cadherin and cadherin-11 (Fig. 4) (Yasuda et al. 2007). Induction of this isoform activated a MAPKKK, TAO2 $\beta$, triggering a signaling pathway leading to endocytosis of $\mathrm{N}$-cadherin. Whether the putative tumor suppressor activity of PCDH8 is based on a similar phenomenon is unknown.

Within the same protocadherin subfamily, protocadherin-10 (PCDH10 or OL-protocadherin) and protocadherin-20 (PCDH20) were also proposed as tumor suppressors (Table 1). First, strong evidence was reported for frequent epigenetic inactivation of PCDH10 in various human cancers but not in matched normal tissues (Miyamoto et al. 2005; Ying et al. 2006; Ying et al. 2007; Yu et al. 2009). For gastric cancer, PCDH10 methylation was detected at early stages of carcinogenesis and was associated with poor prognosis (Yu et al. 2009). Ectopic PCDH10 expression in nasopharyngeal and esophageal carcinoma cell lines reduced clonogenicity, anchorage-independent growth, migration potential, and in vitro invasion into Matrigel (Ying et al. 2006). Re-expression of PCDH10 in gastric cancer cells inhibited tumor growth in mice, induced cell apoptosis, and inhibited cell invasion (Yu et al. 2009). Also, the promoter of the $\mathrm{PCDH} 20$ gene is frequently methylated in human tumors, specifically in nonsmall-cell lung cancers (Imoto et al. 2006). Again, ectopic expression in a carcinoma cell line reduced clonogenicity and anchorage-independent growth. The molecular mechanisms underlying these tumor suppressive functions of protocadherins are unknown.

In contrast to the previously mentioned protocadherins, protocadherin-11Y (PCDH11Y, also named protocadherin-PC) is a candidate proto-oncogene. Human PCDH11X and PCDH11Y are highly homologous and are located in the hominid-specific nonpseudoautosomal homologous region $\mathrm{Xq} 21.3 / \mathrm{Yp} 11.2$, which had undergone duplication by transposition from the $\mathrm{X}$ to the $\mathrm{Y}$ chromosome after the divergence of the hominid and chimpanzee lineages. In other words, $P C D H 11 Y$ is found exclusively in man (Blanco et al. 2000). Transcription occurs mainly in the brain. The encoded PCDH11 proteins belong to the $\delta 1$ protocadherin subfamily (Vanhalst et al. 2005).

The start codon in the PCDH11X transcript is absent from the $P C D H 11 Y$ transcript because of a short genomic deletion. Use of an AUG further downstream results in a PCDH11Y 
protein lacking the signal peptide and therefore remaining cytoplasmic (Fig. 4) (Chen et al. 2002). Transcription of PCDH11Y is upregulated in apoptosis-resistant cell variants compared with the parental prostate carcinoma cell line LNCaP. PCDH11Y mRNA levels are increased in androgen-refractory prostate cancers, and its ectopic expression in human prostate cancer cell lines induced anchorageindependent growth in hormone-deprived medium and tumorigenicity in castrated nude mice (Terry et al. 2006). Its expression correlated with occurrence of nuclear $\beta$-catenin and with increased TCF/Lef transcriptional activity (Yang et al. 2005; Terry et al. 2006). Recently, an interesting link was established between Wnt/ $\beta$-catenin signaling and androgen independence during prostate cancer progression (Placencio et al. 2008; Schweizer et al. 2008; Wang et al. 2008). Although $\beta$-catenin coimmunoprecipitated with PCDH11Y (Chen et al. 2002), the interaction between the two proteins is not direct (our unpublished data).

\section{OTHER CADHERIN-RELATED MOLECULES AND CANCER}

Expression of the mRNA and protein of a cadherin-related protein, named protocadherin LKC or PC-LKC and later renamed protocadherin-24 (Fig. 1), was reported to be reduced in carcinomas derived from the colon, liver, and kidney (Table 1) (Okazaki et al. 2002). Ectopic expression of this cadherin-related protein in human colorectal carcinoma cells (HCT116) reduced tumorigenicity in nude mice by an unknown mechanism.

Another interesting cadherin-related protein is Fat4, which has 34 cadherin repeats and is the homologue of Drosophila Fat (Fig. 1) (Hulpiau and van Roy 2009). In the fly, Fat modulates cell contact inhibition and organ size by functioning upstream of the (Hippo/Salvador)-(Warts/Mats)-YorkieScalloped signaling pathway (reviewed in Harvey and Tapon 2007; Zeng and Hong 2008; Zhao et al. 2008). Several components of this pathway are protein kinases or adaptors, whereas Yorkie is a transcriptional coactivator that is inactivated by cytoplasmic retention on Hippo activation, and Scalloped belongs to the TEAD transcription factor family. Fat appears to be upstream in this pathway and to signal through Expanded, a Merlin-like protein, or through inhibition of Dachs (not to be confused with Dachsous or Ds), an atypical myosin that inhibits Warts. The mechanism by which Expanded activates the Hippo/Salvador complex is unknown. Anyhow, removal of Fat induces overgrowth of imaginal disc tissues. Also, Fat functions in planar cell polarity processes. There is no evidence for homophilic binding in trans between cells expressing Fat (Matakatsu and Blair 2006). In contrast, the ectodomain of Fat can interact with the ectodomain of another huge cadherin-related protein, Dachsous (Ds), on juxtaposed cell surfaces (Figs. 1 and 4). The Fat-Ds interaction can be compared with ligand-receptor binding rather than to cell-cell adhesion, and it might function mainly to activate the intracellular domain of Fat. The intracellular domain of Ds seems to contribute to growth control also independently of the Fat intracellular domain (Matakatsu and Blair 2006).

Each of the Hippo pathway components mentioned above is conserved in mammals, in which the pathway can be abbreviated as (Mst1/Mst2)-(LATS/Mob/WW45)-(YAP/ TAZ)-TEAD (Fig. 4). Several of these proteins or their corresponding genes are mutated, silenced, or overexpressed in human tumors and mouse cancer models (reviewed in Harvey and Tapon 2007). A putative role for mammalian Fat4 as tumor suppressor remained unproven until recently, when Qi et al. (2009) reported that biallelic Fat4 inactivation conferred tumorigenicity to a mouse mammary epithelial cell line (Table 1). Re-expression of Fat4 in Fat4-deficient tumor cells suppressed their tumorigenicity. Moreover, Fat 4 expression was lost in many human breast tumor cell lines and primary tumors, and this silencing was associated with human Fat4 promoter methylation. Nonetheless, loss of Fat 4 by itself is insufficient to generate tumors, as Fat4 knockout mice show various defects, explainable by defective planar cell polarity signaling, but no tumors 
(Saburi et al. 2008). No association with cancer has been reported for mammalian Dachsous homologs.

The human RET protein is a protooncogenic receptor tyrosine kinase with cadherin-like domains in the ectodomain. Bioinformatic analysis and molecular modeling revealed the presence of 4 cadherin-like domains in vertebrate Ret proteins (Fig. 1) (Anders et al. 2001). It was suggested that Ret resulted from recombination of a tyrosine kinase receptor gene and an ancestral cadherin gene during early metazoan evolution. Whether RET can be considered a cell adhesion receptor is undetermined, but its involvement in cancer is beyond doubt (reviewed by Kondo et al. 2006; Zbuk and Eng 2007). Glial cell derived neurotrophic factor (GDNF) ligands and GNDF receptor- $\alpha$ bind the extracellular domain of RET, leading to RET dimerization and autophosphorylation. Constitutive activation can result from missense mutations in Cys residues in the ectodomain or from fusion to PTC in a chimeric oncoprotein. The resulting cancers are various sporadic thyroid carcinomas as well as familial cancers such as the multiple endocrine neoplasias MEN2A and MEN2B (Table 1). The role of the cadherin domains in the RETectodomain is unknown.

\section{CONCLUSIONS AND PERSPECTIVES}

The effectiveness of conventional anticancer treatment is often limited by serious toxicity. Even after 30 years of conventional therapies (surgery, irradiation, chemotherapy, and combinations thereof), overall survival from metastatic cancer has not improved much. Among the causes of therapeutic failure are the lack of adequate tumor specificity and the development of drug resistance. Future anticancer drugs should be made more effective and more selective: They should act on or somehow exploit the specific molecular abnormalities driving malignant progression.

Research during the past 20 years has shown that dysregulation of cadherins contributes to different aspects of cancer progression, including drug resistance, angiogenesis, cancer cell invasion, and metastasis. Thus, cadherins and their regulators can become valuable diagnostic and prognostic indicators, as well as potential therapeutic targets.

The most compelling data for the involvement of the cadherin family in cancer progression are available for E-cadherin. The causal relationship between E-cadherin dysfunction and cancer progression has been convincingly shown both in vitro and in vivo. Furthermore, the clinical relevance of Ecadherin deficiency has been confirmed by immunohistochemical evidence of changes in E-cadherin expression and localization in most human cancers (reviewed in Strumane et al. 2004). Consequently, circulating cadherin fragments received as much attention as potential cancer markers (reviewed in De Wever et al. 2007). Indeed, multiple cadherins are targets for ectodomain shedding because of elevated protease activity in the tumoral microenvironment. However, current experimental data support the use only of soluble $\mathrm{N}$-cadherin as a circulation tumor marker for prostate and pancreas cancers. Expression of $\mathrm{N}$-cadherin and cadherin-11 might be used as indicators of unfavorable diagnosis or poor prognosis because they are normally not expressed in epithelia but are frequently up-regulated in invading cancer cells. A cyclic pentapeptide, $\mathrm{ADH}-1$, has been developed as an extracellular $\mathrm{N}$-cadherin antagonist for use as a systemic anticancer agent (reviewed by De Wever et al. 2007; Mariotti et al. 2007). ADH-1 has entered clinical testing, and has been reported to have significant antitumor activity in a mouse model for pancreatic cancer (Shintani et al. 2008) and to strongly potentiate chemotherapy of human melanoma xenografts (Augustine et al. 2008).

Various aberrations that negatively affect E-cadherin can occur during cancer progression, such as mutations, promoter methylation, and transcriptional repression. In sporadic diffuse gastric cancer and possibly in HDGC, CDH1 mutations are accompanied by epigenetic silencing of the second allele (Grady et al. 2000). This opens the way for future E-cadherin-directed epigenetic therapy by using DNA methylation inhibitors (e.g., 
$5 \mathrm{AzaC}$ ) and histone deacytelase inhibitors (e.g., trichostatin A; Wu et al. 2007), both of which have been shown to reactivate E-cadherin expression in vitro. It is noteworthy that several protocadherins were recently reported to be silenced by promoter methylation in cancers. Nonetheless, one has to consider that reactivating expression of cell-cell adhesion molecules in cancer cells may trigger intrinsic or acquired resistance to anticancer druginduced apoptosis (St Croix and Kerbel 1997).

Further, transcriptional deregulation of epithelial differentiation has been much explored lately (Peinado et al. 2007). As pointed out previously, different transcriptional repressors of E-cadherin have been identified, such as Twist, Snail, and ZEB family members and their respective miRNA regulators. Because of the central role of these transcription factors in EMT and their possible contribution to tumorigenesis, they can be regarded as candidates for molecular targeting (Berx et al. 2007). Specifically inhibiting them by small interfering RNA (siRNA) or by chemical compounds could improve the management of malignant cancer by enhancing E-cadherin expression. Expression of these EMT-driving transcriptional repressors has also been associated with antiapoptotic functions, poor response to pharmacological treatments, and chemoresistance (Yauch et al. 2005; Shah and Gallick 2007). Identification of an EMT signature in tumors could therefore be instrumental to developing more effective therapeutics. For this, we should carefully investigate the aberrations in signaling pathways driving EMT in different tumor types to enable use of pathway-specific inhibitors as anti-invasive cancer therapies. For instance, TGF- $\beta$ is a strong inducer of EMT: It stabilizes and induces the expression of different E-cadherin repressors and can enhance the cancer stem cell phenotype (Mani et al. 2008). Long-term use of TGF- $\beta$ antagonists has been shown to be effective in reducing metastasis in experimental mouse models (Akhurst 2002) and could therefore be a means to block pathological EMT in cancer.

In conclusion, it is most important to investigate further the pleiotropic effects of different cadherins, protocadherins, and other cadherinrelated molecules during cancer progression. This implies unraveling complex regulatory pathways, including molecular inducers, signaling pathways, and molecular effectors, under both physiological and pathological conditions. This is well advanced for classic cadherins, but for numerous other members of the cadherin superfamily, it is still in its infancy. Such scrutiny might eventually lead to development of better tailored anticancer therapies based on cadherin-targeting strategies.

\section{ACKNOWLEDGMENTS}

This research was funded by grants from the FWO, the Geconcerteerde Onderzoeksacties of Ghent University, the Belgian Federation against Cancer, the Association for International Cancer Research (Scotland), and FP7 (TUMIC) of the European Union. We acknowledge Dr. Amin Bredan for critical reading of the manuscript, and the members of our research groups for valuable discussions.

\section{REFERENCES}

Adachi Y, Takeuchi T, Sonobe H, Ohtsuki Y. 2006. An adiponectin receptor, T-cadherin, was selectively expressed in intratumoral capillary endothelial cells in hepatocellular carcinoma: Possible cross talk between T-cadherin and FGF-2 pathways. Virchows Archiv 448: 311-318.

Akhurst RJ. 2002. TGF- $\beta$ antagonists: Why suppress a tumor suppressor? J Clin Invest 109: 1533-1536.

Al-Hajj M, Wicha MS, Benito-Hernandez A, Morrison SJ, Clarke MF. 2003. Prospective identification of tumorigenic breast cancer cells. Proc Natl Acad Sci USA 100: 3983-3988.

Alpaugh ML, Tomlinson JS, Shao ZM, Barsky SH. 1999. A novel human xenograft model of inflammatory breast cancer. Cancer Res 59: 5079-5084.

Anders J, Kjaer S, Ibanez CF. 2001. Molecular modeling of the extracellular domain of the RET receptor tyrosine kinase reveals multiple cadherin-like domains and a calcium-binding site. J Biol Chem 276: 35808-35817.

Augustine CK, Yoshimoto Y, Gupta M, Zipfel PA, Selim MA, Febbo P, Pendergast AM, Peters WP, Tyler DS. 2008. Targeting N-cadherin enhances antitumor activity of cytotoxic therapies in melanoma treatment. Cancer Res 68: 3777-3784.

Becker K-F, Atkinson MJ, Reich U, Huang H-H, Nekarda H, Siewert JR, Höfler H. 1993. Exon skipping in the E-cadherin gene transcript in metastatic human gastric carcinomas. Hum Mol Genet 2: 803-804. 
G. Berx and F. van Roy

Becker KF, Atkinson MJ, Reich U, Becker I, Nekarda H, Siewert JR, Höfler H. 1994. E-cadherin gene mutations provide clues to diffuse type gastric carcinomas. Cancer Res 54: 3845-3852.

Berx G, Cleton-Jansen A-M, Nollet F, de Leeuw WJF, van de Vijver MJ, Cornelisse C, van Roy F. 1995a. E-cadherin is a tumor/invasion suppressor gene mutated in human lobular breast cancers. EMBO J 14: 6107-6115.

Berx G, Staes K, van Hengel J, Molemans F, Bussemakers MJG, van Bokhoven A, van Roy F. 1995b. Cloning and characterization of the human invasion suppressor gene E-cadherin (CDH1). Genomics 26: 281-289.

Berx G, Cleton-Jansen A-M, Strumane K, de Leeuw WJF, Nollet F, van Roy FM, Cornelisse C. 1996. E-cadherin is inactivated in a majority of invasive human lobular breast cancers by truncation mutations throughout its extracellular domain. Oncogene 13: 1919-1925.

Berx G, Becker K-F, Höfler H, van Roy F. 1998. Mutation Update: Mutations of the human E-cadherin (CDH1) gene. Hum Mutat 12: 226-237.

Berx G, Raspe E, Christofori G, Thiery JP, Sleeman JP. 2007. Pre-EMTing metastasis? Recapitulation of morphogenetic processes in cancer. Clin Exp Metastas 24: 587-597.

Birchmeier W, Behrens J. 1994. Cadherin expression in carcinomas: Role in the formation of cell junctions and the prevention of invasiveness. Biochim Biophys Acta Rev Cancer 1198: 11-26.

Bittner M, Meitzer P, Chen Y, Jiang Y, Seftor E, Hendrix M, Radmacher M, Simon R, Yakhini Z, BenDor A, et al. 2000. Molecular classification of cutaneous malignant melanoma by gene expression profiling. Nature 406: 536-540.

Blanco P, Sargent CA, Boucher CA, Mitchell M, Affara NA. 2000. Conservation of PCDHX in mammals; expression of human X/Y genes predominantly in brain. Mamm Genome 11: 906-914.

Blanco MJ, Moreno-Bueno G, Sarrio D, Locascio A, Cano A, Palacios J, Nieto MA. 2002. Correlation of Snail expression with histological grade and lymph node status in breast carcinomas. Oncogene 21: 3241-3246.

Bonnomet A, Nawrocki-Raby B, Strumane K, Gilles C, Kiletzky C, Berx G, van Roy F, Polette M, Birembaut P. 2008. The E-cadherin-repressed hNanos1 gene induces tumor cell invasion by upregulating MT1-MMP expression. Oncogene 27: 3692-3699.

Boussadia O, Kutsch S, Hierholzer A, Delmas V, Kemler R. 2002. E-cadherin is a survival factor for the lactating mouse mammary gland. Mech Develop 115: 53-62.

Bracken CP, Gregory PA, Kolesnikoff N, Bert AG, Wang J, Shannon MF, Goodall GJ. 2008. A double-negative feedback loop between ZEB1-SIP1 and the microRNA-200 family regulates epithelial-mesenchymal transition. Cancer Res 68: 7846-7854.

Brock MV, Hooker CM, Ota-Machida E, Han Y, Guo MZ, Ames S, Glockner S, Piantadosi S, Gabrielson E, Pridham G, et al. 2008. DNA methylation markers and early recurrence in stage I lung cancer. New Engl J Med 358: $1118-1128$.

Brooks-Wilson AR, Kaurah P, Suriano G, Leach S, Senz J, Grehan N, Butterfield YSN, Jeyes J, Schinas J, Bacani J, et al. 2004. Germline E-cadherin mutations in hereditary diffuse gastric cancer: Assessment of 42 new families and review of genetic screening criteria. J Med Genet 41: 508-517.

Burk U, Schubert J, Wellner U, Schmalhofer O, Vincan E, Spaderna S, Brabletz T. 2008. A reciprocal repression between ZEB1 and members of the miR-200 family promotes EMT and invasion in cancer cells. EMBO Rep 9: 582-589.

Bussemakers MJG, Van Bokhoven A, Tomita K, Jansen CFJ, Schalken JA. 2000. Complex cadherin expression in human prostate cancer cells. Int J Cancer 85: 446-450.

Caldas C, Carneiro F, Lynch HT, Yokota J, Wiesner GL, Powell SM, Lewis FR, Huntsman DG, Pharoah PDP, Jankowski JA, et al. 1999. Familial gastric cancer: overview and guidelines for management. J Med Genet 36: 873-880.

Caldas C, Carneiro F, Lynch HT, Yokota J, Wiesner GL, Powell SM, Lewis FR, Huntsman DG, Pharoah PDP, Jankowski JA, et al. 2000. The transcription factor Snail controls epithelial-mesenchymal transitions by repressing E-cadherin expression. Nat Cell Biol 2: 76-83.

Cano A, Perez-Moreno MA, Rodrigo I, Locascio A, Blanco MJ, del Barrio MG, Portillo F, Nieto MA. 2000. The transcription factor Snail controls epithelial-mesenchymal transitions by repressing E-cadherin expression. Nat Cell Biol 2: 76-83.

Carneiro F, Oliveira C, Suriano G, Seruca R. 2008. Molecular pathology of familial gastric cancer, with an emphasis on hereditary diffuse gastric cancer. J Clin Pathol 61: 25-30.

Cavallaro U, Liebner S, Dejana E. 2006. Endothelial cadherins and tumor angiogenesis. Exp Cell Res 312: 659-667.

Chan DW, Lee JMF, Chan PCY, Ng IOL. 2008. Genetic and epigenetic inactivation of T-cadherin in human hepatocellular carcinoma cells. Int J Cancer 123: 1043-1052.

Chang HW, Chow V, Lam KY, Wei WI, Yuen APW. 2002. Loss of E-cadherin expression resulting from promoter hypermethylation in oral tongue carcinoma and its prognostic significance. Cancer 94: 386-392.

Chen MW, Vacherot F, De La Taille A, Gil-Diez-De-Medina S, Shen R, Friedman RA, Burchardt M, Chopin DK, Buttyan R. 2002. The emergence of protocadherin-PC expression during the acquisition of apoptosis-resistance by prostate cancer cells. Oncogene 21: 7861-7871.

Cheng CW, Wu PE, Yu JC, Huang CS, Yue CT, Wu CW, Shen CY. 2001. Mechanisms of inactivation of E-cadherin in breast carcinoma: Modification of the two-hit hypothesis of tumor suppressor gene. Oncogene 20: 3814-3823.

Christoffersen NR, Silahtaroglu A, Orom UA, Kauppinen S, Lund AH. 2007. miR-200b mediates post-transcriptional repression of ZFHX1B. RNA 13: 1172-1178.

Christofori G, Semb H. 1999. The role of the cell-adhesion molecule E-cadherin as a tumour-suppressor gene. Trends Biochem Sci 24: 73-76.

Chu K, Cheng CJ, Ye X, Lee YC, Zurita AJ, Chen DT, Yu-Lee LY, Zhang S, Yeh ET, Hu MC, et al. 2008. Cadherin-11 promotes the metastasis of prostate cancer cells to bone. Mol Cancer Res 6: 1259-1267.

Cleton-Jansen AM, Callen DF, Seshadri R, Goldup S, McCallum B, Crawford J, Powell JA, Settasatian C, van Beerendonk H, Moerland EW, et al. 2001. Loss of 
heterozygosity mapping at chromosome arm 16q in 712 breast tumors reveals factors that influence delineation of candidate regions. Cancer Res 61: 1171-1177.

Corada M, Zanetta L, Orsenigo F, Breviario F, Lampugnani MG, Bernasconi S, Liao F, Hicklin DJ, Bohlen P, Dejana E. 2002. A monoclonal antibody to vascular endothehalcadherin inhibits tumor angiogenesis without side effects on endothelial permeability. Blood 100: 905-911.

Covington MD, Burghardt RC, Parrish AR. 2006 Ischemia-induced cleavage of cadherins in NRK cells requires MT1-MMP (MMP-14). Am J Physiol Renal Physiol 290: F43-F51.

Dames SA, Bang E, Haussinger D, Ahrens T, Engel J, Grzesiek S. 2008. Insights into the low adhesive capacity of human T-cadherin from the NMR structure of Its N-terminal extracellular domain. J Biol Chem 283: 23485-23495.

Davies G, Jiang WG, Mason MD. 2001. Matrilysin mediates extracellular cleavage of E-cadherin from prostate cance cells: A key mechanism in hepatocyte growth factor/ scatter factor-induced cell-cell dissociation and in vitro invasion. Clin Cancer Res 7: 3289-3297.

De Wever O, Derycke L, Hendrix A, De Meerleer G, Godeau F, Depypere H, Bracke M. 2007. Soluble cadherins as cancer biomarkers. Clin Exp Metastas 24: 685-697.

Dejana E. 2004. Endothelial cell-cell junctions: Happy together. Nat Rev Mol Cell Biol 5: 261-270.

Derksen PWB, Liu XL, Saridin F, vanderGulden $\mathrm{H}$, Zevenhoven J, Evers B, vanBeijnum JR, Griffioen AW, Vink J, Krimpenfort P, et al. 2006. Somatic inactivation of E-cadherin and p53 in mice leads to metastatic lobular mammary carcinoma through induction of anoikis resistance and angiogenesis. Cancer Cell 10: 437-449.

Droufakou S, Deshmane V, Roylance R, Hanby A, Tomlinson I, Hart IR. 2001. Multiple ways of silencing E-cadherin gene expression in lobular carcinoma of the breast. Int J Cancer 92: 404-408.

Dunbier A, Guilford P. 2001. Hereditary diffuse gastric cancer. Adv Cancer Res 83: 55-65.

Eger A, Aigner K, Sonderegger S, Dampier B, Oehler S, Schreiber M, Berx G, Cano A, Beug H, Foisner R. 2005. DeltaEF1 is a transcriptional repressor of E-cadherin and regulates epithelial plasticity in breast cancer cells. Oncogene 24: 2375-2385.

Elloul S, Elstrand MB, Nesland JM, Trope CG, Kvalheim G, Goldberg I, Reich R, Davidson B. 2005. Snail, Slug, and Smad-interacting protein 1 as novel parameters of disease aggressiveness in metastatic ovarian and breast carcinoma. Cancer 103: 1631-1643.

Endo K, Ashida K, Miyake N, Terada T. 2001. E-cadherin gene mutations in human intrahepatic cholangiocarcinoma. J Pathol 193: 310-317.

Esteban MA, Tran MG, Harten SK, Hill P, Castellanos MC, Chandra A, Raval R, O’Brien T, Maxwell PH. 2006. Regulation of E-cadherin expression by VHL and hypoxia-inducible factor. Cancer Res 66: 3567-3575.

Evans AJ, Russell RC, Roche O, Burry TN, Fish JE, Chow VWK, Kim WY, Saravanan A, Maynard MA, Gervais ML, et al. 2007. VHL promotes E2 box-dependent E-cadherin transcription by HIF-mediated regulation of SIP1 and snail. Mol Cell Biol 27: 157-169.
Frixen UH, Behrens J, Sachs M, Eberle G, Voss B, Warda A, Löchner D, Birchmeier W. 1991. E-cadherin-mediated cell-cell adhesion prevents invasiveness of human carcinoma cells. J Cell Biol 113: 173-185.

Fujita Y, Krause G, Scheffner M, Zechner D, Leddy HEM, Behrens J, Sommer T, Birchmeier W. 2002. Hakai, a c-Cbl-like protein, ubiquitinates and induces endocytosis of the E-cadherin complex. Nat Cell Biol 4: 222-231.

Ghosh S, Josh MB, Ivanov D, Feder-Mengus C, Spagnoli GC, Martin I, Erne P, Resink TJ. 2007. Use of multicellular tumor spheroids to dissect endothelial cell-tumor cell interactions: A role for T-cadherin in tumor angiogenesis. FEBS Lett 581: 4523-4528.

Gocheva V, Zeng W, Ke DX, Klimstra D, Reinheckel T, Peters C, Hanahan D, Joyce JA. 2006. Distinct roles for cysteine cathepsin genes in multistage tumorigenesis. Genes Dev 20: $543-556$.

Grady WM, Willis J, Guilford PJ, Dunbier AK, Toro TT, Lynch H, Wiesner G, Ferguson K, Eng C, Park JG, et al. 2000. Methylation of the $\mathrm{CDH} 1$ promoter as the second genetic hit in hereditary diffuse gastric cancer. Nat Genet 26: 16-17.

Graff JR, Greenberg VE, Herman JG, Westra WH, Boghaert ER, Ain KB, Saji M, Zeiger MA, Zimmer SG, Baylin SB. 1998. Distinct patterns of E-cadherin CpG island methylation in papillary, follicular, Hurthle's cell, and poorly differentiated human thyroid carcinoma. Cancer Res 58: 2063-2066.

Graff JR, Herman JG, Lapidus RG, Chopra H, Xu R, Jarrard DF, Isaacs WB, Pitha PM, Davidson NE, Baylin SB. 1995. E-cadherin expression is silenced by DNA hypermethylation in human breast and prostate carcinomas. Cancer Res 55: 5195-5199.

Graff JR, Gabrielson E, Fujii H, Baylin SB, Herman JG. 2000 Methylation patterns of the E-cadherin $5^{\prime} \mathrm{CpG}$ island are unstable and reflect the dynamic, heterogeneous loss of E-cadherin expression during metastatic progression. J Biol Chem 275: 2727-2732.

Gregory PA, Bert AG, Paterson EL, Barry SC, Tsykin A, Farshid G, Vadas MA, Khew-Goodall Y, Goodall GJ. 2008. The miR-200 family and miR-205 regulate epithelial to mesenchymal transition by targeting ZEB1 and SIP1. Nat Cell Biol 10: 593-601.

Guaita S, Puig I, Franci C, Garrido M, Dominguez D, Batlle E, Sancho E, Dedhar S, De Herreros AG, Baulida J. 2002. Snail induction of epithelial to mesenchymal transition in tumor cells is accompanied by MUC1 repression and ZEB1 expression. J Biol Chem 277: 39209-39216.

Guilford P, Hopkins J, Harraway J, McLeod M, McLeod N, Harawira P, Taite H, Scoular R, Miller A, Reeve AE. 1998. E-cadherin germline mutations in familial gastric cancer. Nature 392: 402-405.

Harvey K, Tapon N. 2007. The Salvador-Warts-Hippo pathway - an emerging tumour-suppressor network. Nat Rev Cancer 7: 182-191.

Hazan RB, Kang L, Whooley BP, Borgen PI. 1997. $\mathrm{N}$-cadherin promotes adhesion between invasive breast cancer cells and the stroma. Cell Adhes Commun 4: 399-411.

Hazan RB, Phillips GR, Qiao RF, Norton L, Aaronson SA. 2000. Exogenous expression of $\mathrm{N}$-cadherin in breast 
G. Berx and F. van Roy

cancer cells induces cell migration, invasion, and metastasis. J Cell Biol 148: 779-790.

Hazan RB, Qiao R, Keren R, Badano I, Suyama K. 2004 Cadherin switch in tumor progression. Ann N Y Acad Sci 1014: 155-163.

Hebbard LW, Garlatti M, Young LJT, Cardiff RD, Oshima RG, Ranscht B. 2008. T-cadherin supports anglogenesis and adiponectin association with the vasculature in a mouse mammary tumor model. Cancer Res 68: 1407-1416.

Hendrix MJ, Seftor EA, Meltzer PS, Gardner LM, Hess AR, Kirschmann DA, Schatteman GC, Seftor RE. 2001. Expression and functional significance of VE-cadherin in aggressive human melanoma cells: Role in vasculogenic mimicry. Proc Natl Acad Sci USA 98: 8018-8023.

Hibi K, Kodera Y, Ito K, Akiyama S, Nakao A. 2004 Methylation pattern of CDH13 gene in digestive tract cancers. Br J Cancer 91: 1139-1142.

Huang ZY, Wu YL, Hedrick N, Gutmann DH. 2003. T-cadherin-mediated cell growth regulation involves $\mathrm{G}(2)$ phase arrest and requires p21 (CIP1/WAF1) expression. Mol Cell Biol 23: 566-578.

Hug C, Wang J, Ahmad NS, Bogan JS, Tsao TS, Lodish HF. 2004. T-cadherin is a receptor for hexameric and high-molecular- weight forms of Acrp30/adiponectin. Proc Natl Acad Sci USA 101: 10308-10313.

Hulit J, Suyama K, Chung S, Keren R, Agiostratidou G, Shan W, Dong X, Williams TM, Lisanti MP, Knudsen K, et al. 2007. N-cadherin signaling potentiates mammary tumor metastasis via enhanced extracellular signalregulated kinase activation. Cancer Res 67: 3106-3116.

Hulpiau P, van Roy F. 2009. Molecular evolution of the cadherin superfamily. Int J Biochem Cell Biol 41: 343-369.

Hurteau GJ, Carlson JA, Spivack SD, Brock GJ. 2007. Overexpression of the microRNA hsa-miR-200c leads to reduced expression of transcription factor 8 and increased expression of E-cadherin. Cancer Res 67: $7972-7976$.

Imoto I, Izumi H, Yokoi S, Hosoda H, Shibata T, Hosoda F, Ohki N, Hirohashi S, Inazawa J. 2006. Frequent silencing of the candidate tumor suppressor PCDH20 by epigenetic mechanism in non-small-cell lung cancers. Cancer Res 66: 4617-4626.

Jeanes A, Gottardi CJ, Yap AS. 2008. Cadherins and cancer: How does cadherin dysfunction promote tumor progression? Oncogene 27: 6920-6929.

Jin Z, Cheng YL, Olaru A, Kan T, Yang J, Paun B, Ito T, Hamilton JP, David S, Agarwal R, et al. 2008. Promoter hypermethylation of CDH13 is a common, early event in human esophageal adenocarcinogenesis and correlates with clinical risk factors. Int J Cancer 123: 2331-2336.

Johnson SK, Ramani VC, Hennings L, Haun RS. 2007. Kallikrein 7 enhances pancreatic cancer cell invasion by shedding E-cadherin. Cancer 109: 1811-1820.

Jones S, Zhang XS, Parsons DW, Lin JCH, Leary RJ, Angenendt P, Mankoo P, Carter H, Kamiyama H, Jimeno A, et al. 2008. Core signaling pathways in human pancreatic cancers revealed by global genomic analyses. Science 321: 1801-1806.

Kanai Y, Ushijima S, Tsuda H, Sakamoto M, Hirohashi S. 2000. Aberrant DNA methylation precedes loss of heterozygosity on chromosome 16 in chronic hepatitis and liver cirrhosis. Cancer Lett 148: 73-80.

Kanazawa T, Watanabe T, Kazama S, Tada T, Koketsu S, Nagawa H. 2002. Poorly differentiated adenocarcinoma and mucinous carcinoma of the colon and rectum show higher rates of loss of heterozygosity and loss of E-cadherin expression due to methylation of promoter region. Int J Cancer 102: 225-229.

Katafiasz BJ, Nieman MT, Wheelock MJ, Johnson KR. 2003. Characterization of cadherin-24, a novel alternatively spliced type II cadherin. J Biol Chem 278: 27513-27519.

Kawakami M, Staub J, Cliby W, Hartmann L, Smith DI, Shridhar V. 1999. Involvement of H-cadherin (CDH13) on $16 \mathrm{q}$ in the region of frequent deletion in ovarian cancer. Int J Oncol 15: 715-720.

Kim JS, Han JH, Shim YM, Park J, Kim DH. 2005. Aberrant methylation of $\mathrm{H}$-Cadherin (CDH13) promoter is associated with tumor progression in primary nonsmall cell lung carcinoma. Cancer 104: 1825-1833.

Kleer CG, van Golen KL, Braun T, Merajver SD. 2001. Persistent E-cadherin expression in inflammatory breast cancer. Modern Pathol 14: 458-464.

Klucky B, Mueller R, Vogt I, Teurich S, Hartenstein B, Breuhahn K, Flechtenmacher C, Angel P, Hess J. 2007. Kallikrein 6 induces E-cadherin shedding and promotes cell proliferation, migration, and invasion. Cancer Res 67: 8198-8206.

Knudsen KA, Sauer C, Johnson KR, Wheelock MJ. 2005. Effect of N-cadherin misexpression by the mammary epithelium in mice. J Cell Biochem 95: 1093-1107.

Koizume S, Tachibana K, Sekiya T, Hirohashi S, Shiraishi M. 2002. Heterogeneity in the modification and involvement of chromatin components of the CpG island of the silenced human CDH1 gene in cancer cells. Nucleic Acids Res 30: 4770-4780.

Kondo T, Ezzat S, Asa SL. 2006. Pathogenetic mechanisms in thyroid follicular-cell neoplasia. Nat Rev Cancer 6: 292-306.

Korpal M, Lee ES, Hu G, Kang Y. 2008. The miR-200 family inhibits epithelial-mesenchymal transition and cancer cell migration by direct targeting of E-cadherin transcriptional repressors ZEB1 and ZEB2. J Biol Chem 283: 14910-14914.

Krishnamachary B, Zagzag D, Nagasawa H, Rainey K, Okuyama H, Baek JH, Semenza GL. 2006. Hypoxia-inducible factor-1-dependent repression of Ecadherin in von Hippel-Lindau tumor suppressor-null renal cell carcinoma mediated by TCF3, ZFHX1A, and ZFHX1B. Cancer Res 66: 2725-2731.

Lee SW. 1996. H-cadherin, a novel cadherin with growth inhibitory functions and diminished expression in human breast cancer. Nat Med 2: 776-782.

Lee SW, Reimer CL, Campbell DB, Cheresh P, Duda RB, Kocher O. 1998. H-cadherin expression inhibits in vitro invasiveness and tumor formation in vivo. Carcinogenesis (London) 19: 1157-1159.

Ley TJ, Mardis ER, Ding L, Fulton B, McLellan MD, Chen K, Dooling D, Dunford-Shore BH, McGrath S, Hickenbotham M, et al. 2008. DNA sequencing of a cytogenetically normal acute myeloid leukaemia genome. Nature 456: 66-72. 
Liang Y, Ridzon D, Wong L, Chen C. 2007. Characterization of microRNA expression profiles in normal human tissues. BMC Genomics 8: 166.

Lochter A, Galosy S, Muschler J, Freedman N, Werb Z, Bissell MJ. 1997. Matrix metalloproteinase stromelysin-1 triggers a cascade of molecular alterations that leads to stable epithelial-to-mesenchymal conversion and a premalignant phenotype in mammary epithelial cells. $J$ Cell Biol 139: 1861-1872.

Loges S, Roncal C, Carmeliet P. 2008. Development of targeted angiogenic medicine. J Thromb Haemost 7: 21-33.

Lombaerts M, van Wezel T, Philippo K, Dierssen JWF, Zimmerman RME, Oosting J, van Eijk R, Eilers PH, van De Water B, Cornelisse CJ, et al. 2006. E-cadherin transcriptional downregulation by promoter methylation but not mutation is related to epithelial-tomesenchymal transition in breast cancer cell lines. $\mathrm{Br} \mathrm{J}$ Cancer 94: 661-671.

Lopez T, Hanahan D. 2002. Elevated levels of IGF-1 receptor convey invasive and metastatic capability in a mouse model of pancreatic islet tumorigenesis. Cancer Cell 1: 339-353.

Lubensky IA, Gnarra JR, Bertheau P, Walther MM, Linehan WM, Zhuang Z. 1996. Allelic deletions of the VHL gene detected in multiple microscopic clear cell renal lesions in von Hippel-Lindau disease patients. Am J Pathol 149: 2089-2094.

Machado JC, Oliveira C, Carvalho R, Soares P, Berx G, Caldas C, Seruca R, Carneiro F, Sobrinho-Simões M. 2001. E-cadherin gene (CDH1) promoter methylation as the second hit in sporadic diffuse gastric carcinoma. Oncogene 20: 1525-1528.

Mani SA, Guo W, Liao MJ, Eaton EN, Ayyanan A, Zhou AY, Brooks M, Reinhard F, Zhang CC, Shipitsin M, et al 2008. The epithelial-mesenchymal transition generates cells with properties of stem cells. Cell 133: 704-715.

Maniotis AJ, Folberg R, Hess A, Seftor EA, Gardner LM, Pe'er J, Trent JM, Meltzer PS, Hendrix MJ. 1999. Vascular channel formation by human melanoma cells in vivo and in vitro: Vasculogenic mimicry. Am J Pathol 155: 739-752.

Mansouri M, Rose PP, Moses AV, Fruh K. 2008. Remodeling of endothelial adherens junctions by Kaposi's sarcoma-associated herpesvirus. J Virol 82: 9615-9628.

Marambaud P, Wen PH, Dutt A, Shioi J, Takashima A, Siman R, Robakis NK. 2003. A CBP binding transcriptional repressor produced by the PS1/epsilon-cleavage of N-cadherin is inhibited by PS1 FAD mutations. Cell 114: 635-645.

Mariotti A, Perotti A, Sessa C, Ruegg C. 2007. N-cadherin as a therapeutic target in cancer. Expert Opin Investig Drug 16: $451-465$.

Martin TA, Goyal A, Watkins G, Jiang WG. 2005. Expression of the transcription factors snail, slug, and twist and their clinical significance in human breast cancer. Ann Surg Oncol 12: 488-496.

Maruyama R, Toyooka S, Toyooka KO, Harada K, Virman AK, Zochbauer-Muller S, Farinas AJ, Vakar-Lopez F Minna JD, Sagalowsky A, et al. 2001. Aberrant promoter methylation profile of bladder cancer and its relationship to clinicopathological features. Cancer Res 61: 8659-8663.
Masciari S, Larsson N, Senz J, Boyd N, Kaurah P, Kandel MJ, Harris LN, Pinheiro HC, Troussard A, Miron P, et al. 2007. Germline E-cadherin mutations in familial lobular breast cancer. J Med Genet 44: 726-731.

Matakatsu H, Blair SS. 2006. Separating the adhesive and signaling functions of the Fat and Dachsous protocadherins. Development 133: 2315-2324.

May C, Doody JF, Abdullah R, Balderes P, Xu X, Chen CP, Zhu Z, Shapiro L, Kussie P, Hicklin DJ, et al. 2005. Identification of a transiently exposed VE-cadherin epitope that allows for specific targeting of an antibody to the tumor neovasculature. Blood 105: 4337-4344.

Miotto E, Sabbioni S, Veronese A, Callin GA, Gullini CS, Liboni A, Gramantieri L, Bolondi L, Ferrazzi E, Gafa R, et al. 2004. Frequent aberrant methylation of the $\mathrm{CDH} 4$ gene-promoter in human colorectal and gastric cancer. Cancer Res 64: 8156-8159.

Miyamoto K, Fukutomi T, Akashi-Tanaka S, Hasegawa T, Asahara T, Sugimura T, Ushijima T. 2005. Identification of 20 genes aberrantly methylated in human breast cancers. Int J Cancer 116: 407-414.

Mohamed MM, Sloane BF. 2006. Cysteine cathepsins: Multifunctional enzymes in cancer. Nat Rev Cancer 6: 764-775.

Moody SE, Perez D, Pan TC, Sarkisian CJ, Portocarrero CP, Sterner CJ, Notorfrancesco KL, Cardiff RD, Chodosh LA. 2005. The transcriptional repressor snail promotes mammary tumor recurrence. Cancer Cell 8: 197-209.

Morel AP, Lievre M, Thomas C, Hinkal G, Ansieau S, Puisieux A. 2008. Generation of breast cancer stem cells through epithelial-mesenchymal transition. PLoS ONE 3: e2888.

Mukoyama Y, Zhou SX, Miyachi Y, Matsuyoshi N. 2005 T-cadherin negatively regulates the proliferation of cutaneous squamous carcinoma cells. J Invest Dermatol 124: $833-838$.

Najy AJ, Day KC, Day ML. 2008. The ectodomain shedding of E-cadherin by ADAM15 supports ErbB receptor activation. J Biol Chem 283: 18393-18401.

Nam JS, Ino Y, Kanai Y, Sakamoto M, Hirohashi S. 2004. 5-Aza-2'-deoxycytidine restores the E-cadherin system in E- cadherin-silenced cancer cells and reduces cancer metastasis. Clin Exp Metastas 21: 49-56.

Naora H, Montell DJ. 2005. Ovarian cancer metastasis: Integrating insights from disparate model organisms. Nat Rev Cancer 5: 355-366.

Nass SJ, Herman JG, Gabrielson E, Iversen PW, Parl FF Davidson NE, Graff JR. 2000. Aberrant methylation of the estrogen receptor and E-cadherin $5{ }^{\prime} \mathrm{CpG}$ islands increases with malignant progression in human breast cancer. Cancer Res 60: 4346-4348.

Natt E, Magenis RE, Zimmer J, Mansouri A, Scherer G. 1989. Regional assignment of the human loci for uvomorulin (UVO) and chymotrypsinogen B (CTRB) with the help of two overlapping deletions on the long arm of chromosome 16. Cytogenet Cell Genet 50: $145-148$.

Navaratna D, Maestas J, McGuire PG, Das A. 2008. Suppression of retinal neovascularization with an antagonist to vascular endothelial cadherin. Arch Ophthalmol 126: $1082-1088$ 
G. Berx and F. van Roy

Neben K, Korshunov A, Benner A, Wrobel G, Hahn M, Kokocinski F, Golanov A, Joos S, Lichter P. 2004 Microarray-based screening for molecular markers in medulloblastoma revealed STK15 as independent predictor for survival. Cancer Res 64: 3103-3111.

Nieman MT, Prudoff RS, Johnson KR, Wheelock MJ. 1999. $\mathrm{N}$-cadherin promotes motility in human breast cancer cells regardless of their E-cadherin expression. J Cell Biol 147: 631-643.

Noë V, Fingleton B, Jacobs K, Crawford HC, Vermeulen S, Steelant W, Bruyneel E, Matrisian LM, Mareel M. 2001 Release of an invasion promoter E-cadherin fragment by matrilysin and stromelysin-1. J Cell Sci 114: 111-118.

Ogama Y, Ouchida M, Yoshino T, Ito S, Takimoto H, Shiote Y, Ishimaru F, Harada M, Tanimoto M, Shimizu K. 2004. Prevalent hyper-methylation of the $\mathrm{CDH} 13$ gene promoter in malignant B cell lymphomas. Int J Oncol 25: 685-691.

Okazaki N, Takahashi N, Kojima S, Masuho Y, Koga H. 2002. Protocadherin LKC, a new candidate for a tumor suppressor of colon and liver cancers, its association with contact inhibition of cell proliferation. Carcinogenesis 23: 1139-1148.

Oliveira C, Seruca R, Carneiro F. 2006. Genetics, pathology, and clinics of familial gastric cancer. Int J Surg Pathol 14: 21-33.

Paredes J, Stove C, Stove V, Milanezi F, VanMarck V, Derycke L, Mareel M, Bracke M, Schmitt F. 2004. P-cadherin is up-regulated by the antiestrogen ICI 182,780 and promotes invasion of human breast cancer cells. Cancer Res 64: 8309-8317.

Paredes J, Albergaria A, Oliveira JT, Jeronimo C, Milanezi F, Schmitt FC. 2005. P-cadherin overexpression is an indicator of clinical outcome in invasive breast carcinomas and is associated with $\mathrm{CDH} 3$ promoter hypomethylation. Clin Cancer Res 11: 5869-5877.

Paredes J, Correia AL, Ribeiro AS, Albergaria A, Milanezi F, Schmitt FC. 2007. P-cadherin expression in breast cancer: A review. Breast Cancer Res 9: 214

Park SM, Gaur AB, Lengyel E, Peter ME. 2008. The miR-200 family determines the epithelial phenotype of cancer cells by targeting the E-cadherin repressors ZEB1 and ZEB2. Genes Dev 22: 894-907.

Peinado H, Olmeda D, Cano A. 2007. Snail, Zeb and bHLH factors in tumour progression: An alliance against the epithelial phenotype? Nat Rev Cancer 7: 415-428.

Pereira PS, Teixeira A, Ferreira P, Fernandes J, Oliveira C, Seruca R, Suriano G, Casares F. 2006. E-cadherin missense mutations, associated with hereditary diffuse gastric cancer (HDGC) syndrome, display distinct invasive behaviors and genetic interactions with the Wnt and Notch pathways in Drosophila epithelia. Hum Mol Genet 15: 1704-1712.

Perl AK, Wilgenbus P, Dahl U, Semb H, Christofori G. 1998. A causal role for E-cadherin in the transition from adenoma to carcinoma. Nature 392: 190-193.

Pharoah PDP, Guilford P, Caldas C. 2001. Incidence of gastric cancer and breast cancer in $\mathrm{CDH} 1$ (E- cadherin) mutation carriers from hereditary diffuse gastric cancer families. Gastroenterology 121: 1348-1353.

Philippova M, Banfi A, Ivanov D, Gianni-Barrera R, Allenspach R, Erne P, Resink T. 2006. Atypical
GPI-anchored T-cadherin stimulates angiogenesis in vitro and in vivo. Arterioscler Thromb Vasc Biol 26: 2222-2230.

Philippova M, Ivanov D, Joshi MB, Kyriakakis E, Rupp K, Afonyushkin T, Bochkov V, Erne P, Resink TJ. 2008. Identification of proteins associating with glycosylphosphatidylinositol-anchored T-cadherin on the surface of vascular endothelial cells: Role for Grp78/BiP in T-cadherin-dependent cell survival. Mol Cell Biol 28: 4004-4017.

Pishvaian MJ, Feltes CM, Thompson P, Bussemakers MJ, Schalken JA, Byers SW. 1999. Cadherin-11 is expressed in invasive breast cancer cell lines. Cancer Res 59: 947-952.

Placencio VR, Sharif-Afshar AR, Li XH, Huang HX, Uwamariya C, Neilson EG, Shen NM, Matusik RJ, Hayward SW, Bhowmick NA. 2008. Stromal transforming growth factor- $\beta$ signaling mediates prostatic response to androgen ablation by paracrine Wnt activity. Cancer Res 68: 4709-4718.

Qi C, Zhu YT, Hu L, Zhu YJ. 2009. Identification of Fat4 as a candidate tumor suppressor gene in breast cancers. Int $J$ Cancer 124: 793-798.

Ranscht B, Dours-Zimmermann MT. 1991. T-cadherin, a novel cadherin cell adhesion molecule in the nervous system lacks the conserved cytoplasmic region. Neuron 7: 391-402.

Redies C, Vanhalst K, van Roy F. 2005. Deltaprotocadherins: Unique structures and functions. Cell Mol Life Sci 62: 2840-2852.

Riou P, Saffroy R, Chenailler C, Franc B, Gentile C, Rubinstein E, Resink T, Debuire B, PiatierTonneau D, Lemoine A. 2006. Expression of T-cadherin in tumor cells influences invasive potential of human hepatocellular carcinoma. FASEB J 20: 2291-2301.

Risinger JI, Berchuck A, Kohler MF, Boyd J. 1994. Mutations of the E-cadherin gene in human gynecologic cancers. Nat Genet 7: 98-102.

Roman-Gomez J, Castillejo JA, Jimenez A, Cervantes $\mathrm{F}$, Boque C, Hermosin L, Leon A, Granena A, Colomer D, Heiniger A, et al. 2003. Cadherin-13, a mediator of calcium-dependent cell-cell adhesion, is silenced by methylation in chronic myeloid leukemia and correlates with pretreatment risk profile and cytogenetic response to interferon alfa. J Clin Oncol 21: 1472-1479.

Rosivatz E, Becker I, Specht K, Fricke E, Luber B, Busch R, Hofler H, Becker KF. 2002. Differential expression of the epithelial-mesenchymal transition regulators Snail, SIP1, and Twist in gastric cancer. Am J Pathol 161: 1881-1891.

Russell RC, Ohh M. 2007. The role of VHL in the regulation of E-cadherin - A new connection in an old pathway. Cell Cycle 6: 56-59.

Saburi S, Hester I, Fischer E, Pontoglio M, Eremina V, Gessler M, Quaggin SE, Harrison R, Mount R, McNeill H. 2008. Loss of Fat 4 disrupts PCP signaling and oriented cell division and leads to cystic kidney disease. Nat Genet 40: 1010-1015.

Saito T, Oda Y, Sugimachi K, Kawaguchi K, Tamiya S, Tanaka K, Matsuda S, Sakamoto A, Iwamoto Y, Tsuneyoshi M. 2001. E-cadherin gene mutations frequently occur in 
synovial sarcoma as a determinant of histological features. Am J Pathol 159: 2117-2124.

Sakai M, Hibi K, Koshikawa K, Inoue S, Takeda S, Kaneko T, Nakao A. 2004. Frequent promoter methylation and gene silencing of $\mathrm{CDH} 13$ in pancreatic cancer. Cancer Sci 95: $588-591$.

Sanders DSA, Blessing K, Hassan GAR, Bruton R, Marsden JR, Jankowski J. 1999. Alterations in cadherin and catenin expression during the biological progression of melanocytic tumours. J Clin Pathol Mol Pathol 52: $151-157$.

Sarrio D, Rodriguez-Pinilla SM, Hardisson D, Cano A, Moreno-Bueno G, Palacios J. 2008. Epithelialmesenchymal transition in breast cancer relates to the basal-like phenotype. Cancer Res 68: 989-997.

Sato M, Mori Y, Sakurada A, Fujimura S, Horii A. 1998. The $\mathrm{H}$-cadherin (CDH13) gene is inactivated in human lung cancer. Hum Genet 103: 96-101.

Schweizer L, Rizzo CA, Spires TE, Platero JS, Wu Q, Lin TA, Gottardis MM, Attar RM. 2008. The androgen receptor can signal through Wnt $/ \beta$-Catenin in prostate cancer cells as an adaptation mechanism to castration levels of androgens. BMC Cell Biol 9: 4

Shah AN, Gallick GE. 2007. Src, chemoresistance and epithelial to mesenchymal transition: Are they related? Anti-cancer drugs 18: 371-375.

Shen Y, Hirsch DS, Sasiela CA, Wu WJ. 2008. Cdc42 regulates E-cadherin ubiquitination and degradation through an epidermal growth factor receptor to Src-mediated pathway. J Biol Chem 283: 5127-5137.

Shintani Y, Fukumoto Y, Chaika N, Grandgenett PM, Hollingsworth MA, Wheelock MJ, Johnson KR. 2008. ADH-1 suppresses $\mathrm{N}$-cadherin-dependent pancreatic cancer progression. Int J Cancer 122: 71-77.

Simoes-Correia J, Figueiredo J, Oliveira C, van Hengel J, Seruca R, van Roy F, Suriano G. 2008. Endoplasmic reticulum quality control: A new mechanism of E-cadherin regulation and its implication in cancer. Hum $\mathrm{Mol}$ Genet 17: 3566-3576.

Soares P, Berx G, van Roy F, Sobrinho-Simões M. 1997. E-cadherin gene alterations are rare events in thyroid tumors. Int J Cancer 70: 32-38.

Spaderna S, Schmalhofer O, Hlubek F, Berx G, Eger A, Merkel S, Jung A, Kirchner T, Brabletz T. 2006. A transient, EMT-linked loss of basement membranes indicates metastasis and poor survival in colorectal cancer. Gastroenterology 131: 830-840.

Spaderna S, Schmalhofer O, Wahlbuhl M, Dimmler A, Bauer K, Sultan A, Hlubek F, Jung A, Strand D, Eger A, et al. 2008. The transcriptional repressor ZEB1 promotes metastasis and loss of cell polarity in cancer. Cancer Res 68: $537-544$.

St Croix BS, Kerbel RS. 1997. Cell adhesion and drug resistance in cancer. Curr Opin Oncol 9: 549-556.

Strathdee G. 2002. Epigenetic versus genetic alterations in the inactivation of E-cadherin. Semin Cancer Biol 12: 373-379.

Strumane K, Berx G, van Roy F. 2004. Cadherins in cancer. In Cell adhesion (ed. Behrens J., Nelson J.), Handbook of Experimental Pharmacology Vol. 165, pp. 69-103. Springer-Verlag, Heidelberg.
Strumane K, Bonnomet A, Stove C, Vandenbroucke R, Nawrocki-Raby B, Bruyneel E, Mareel M, Birembaut P, Berx G, van Roy F. 2006. E-cadherin regulates human Nanos1, which interacts with p120ctn and induces tumor cell migration and invasion. Cancer Res 66: 10007-10015.

Sundfeldt K. 2003. Cell-cell adhesion in the normal ovary and ovarian tumors of epithelial origin; an exception to the rule. Mol Cell Endocrinol 202: 89-96.

Suriano G, Yew S, Ferreira P, Senz J, Kaurah P, Ford JM, Longacre TA, Norton JA, Chun N, Young S, et al. 2005 Characterization of a recurrent germ line mutation of the E-cadherin gene: Implications for genetic testing and clinical management. Clin Cancer Res 11: 5401-5409.

Suyama K, Shapiro I, Guttman M, Hazan RB. 2002. A signaling pathway leading to metastasis is controlled by N-cadherin and the FGF receptor. Cancer Cell 2: 301-314.

Symowicz J, Adley BP, Gleason KJ, Johnson JJ, Ghosh S, Fishman DA, Hudson LG, Stack MS. 2007. Engagement of collagen-binding integrins promotes matrix metalloproteinase-9-dependent E-cadherin ectodomain shedding in ovarian carcinoma cells. Cancer Res 67: 2030-2039.

Taddei I, Piazzini M, Bartoletti R, Dal Canto M, Sardi I. 2000. Molecular alterations of E-cadherin gene: Possible role in human bladder carcinogenesis. Int J Mol Med 6: 201-208.

Takeuchi T, Ohtsuki Y. 2001. Recent progress in T-cadherin (CDH13, H-cadherin) research. Histol Histopathol 16: 1287-1293.

Takeuchi T, Liang SB, Matsuyoshi N, Zhou SX, Miyachi Y, Sonobe H, Ohtsuki Y. 2002a. Loss of T-cadherin (CDH13, H-cadherin) expression in cutaneous squamous cell carcinoma. Lab Invest 82: 1023-1029.

Takeuchi T, Liang SB, Ohtsuki Y. 2002b. Downregulation of expression of a novel cadherin molecule, $\mathrm{T}$ - cadherin, in basal cell carcinoma of the skin. Mol Carcinogen 35: 173-179.

Takeuchi T, Adachi Y, Ohtsuki Y, Furihata M. 2007. Adiponectin receptors, with special focus on the role of the third receptor, T-cadherin, in vascular disease. Med Mol Morphol 40: 115-120.

Tamura D, Hiraga T, Myoui A, Yoshikawa H, Yoneda T. 2008. Cadherin-11-mediated interactions with bone marrow stromal/osteoblastic cells support selective colonization of breast cancer cells in bone. Int J Oncol 33: $17-24$.

Taniuchi K, Nakagawa H, Hosokawa M, Nakamura T, Eguchi H, Ohigashi F, Ishikawa O, Katagiri T, Nakamura Y. 2005. Overexpressed P-cadherin/CDH3 promotes motility of pancreatic cancer cells by interacting with p120ctn and activating Rho-family GTPases. Cancer Res 65: 3092-3099.

Terry S, Queires L, Gil-Diez-de-Medina S, Chen MW, de la Taille A, Allory Y, Tran PL, Abbou CC, Buttyan R, Vacherot F. 2006. Protocadherin-PC promotes androgenindependent prostate cancer cell growth. Prostate 66: $1100-1113$.

Thomas G, Jacobs KB, Yeager M, Kraft P, Wacholder S, Orr $\mathrm{N}$, Yu K, Chatterjee N, Welch R, Hutchinson A, et al. 
G. Berx and F. van Roy

2008. Multiple loci identified in a genome-wide association study of prostate cancer. Nat Genet 40: 310-315.

Tinkle CL, Lechler T, Pasolli HA, Fuchs E. 2004. Conditional targeting of E-cadherin in skin: Insights into hyperproliferative and degenerative responses. Proc Natl Acad Sci USA 101: 552-557.

Tomita K, van Bokhoven A, van Leenders G, Ruijter ETG, Jansen CFJ, Bussemakers MJG, Schalken JA. 2000. Cadherin switching in human prostate cancer progression. Cancer Res 60: 3650-3654.

Toyooka KO, Toyooka S, Virmani AK, Sathyanarayana UG, Euhus DM, Gilcrease M, Minna JD, Gazdar AF. 2001. Loss of expression and aberrant methylation of the CDH13 (H-cadherin) gene in breast and lung carcinomas. Cancer Res 61: 4556-4560.

Toyooka S, Toyooka KO, Harada K, Miyajima K, Makarla P, Sathyanarayana UG, Yin J, Sato F, Shivapurkar N, Meltzer SJ, et al. 2002. Aberrant methylation of the CDH13 (H-cadherin) promoter region in colorectal cancers and adenomas. Cancer Res 62: 3382-3386.

Tunggal JA, Helfrich I, Schmitz A, Schwarz H, Gunzel D, Fromm M, Kemler R, Krieg T, Niessen CM. 2005 E-cadherin is essential for in vivo epidermal barrier function by regulating tight junctions. EMBO $J$ 24: 1146- 1156 .

Unterseher F, Hefele JA, Giehl K, DeRobertis EM, Wedlich D, Schambony A. 2004. Paraxial protocadherin coordinates cell polarity during convergent extension via Rho A and JNK. EMBO J 23: 3259-3269.

van Hengel J, van Roy F. 2007. Diverse functions of p120ctn in tumors. Biochim Biophys Acta-Mol Cell Res 1773: $78-88$.

Van Marck V, Stove C, Van Den Bossche K, Stove V, Paredes J, Vander Haeghen Y, Bracke M. 2005. P-cadherin promotes cell-cell adhesion and counteracts invasion in human melanoma. Cancer Res: 8774-8783.

van Roy F, Berx G. 2008. The cell-cell adhesion molecule E-cadherin. Cell Mol Life Sci 65: 3756-3788.

Vandewalle C, Comijn J, De Craene B, Vermassen P, Bruyneel E, Andersen H, Tulchinsky E, van Roy F, Berx G. 2005. SIP1/ZEB2 induces EMT by repressing genes of different epithelial cell-cell junctions. Nucleic Acids Res 33: 6566-6578.

Vanhalst K, Kools P, Staes K, van Roy F, Redies C. 2005. Delta-protocadherins: A gene family expressed differentially in the mouse brain. Cell Mol Life Sci 62: 1247-1259.

Vecsey-Semjen B, Becker KF, Sinski A, Blennow E, Vietor I, Zatloukal K, Beug H, Wagner E, Huber LA. 2002. Novel colon cancer cell lines leading to better understanding of the diversity of respective primary cancers. Oncogene 21: 4646-4662.

Vestal DJ, Ranscht B. 1992. Glycosyl phosphatidylinositolanchored T-cadherin mediates calcium-dependent, homophilic cell adhesion. J Cell Biol 119: 451-461.

Vleminckx K, Vakaet L Jr, Mareel M, Fiers W, van Roy F. 1991. Genetic manipulation of E-cadherin expression by epithelial tumor cells reveals an invasion suppressor role. Cell 66: 107-119.

Waha A, Guntner S, Huang THM, Yan PS, Arslan B, Pietsch T, Wiestler OD. 2005. Epigenetic silencing of the protocadherin family member PCDH- $\gamma$-A11 in astrocytomas. Neoplasia 7: 193-199.

Wang XD, Wang BE, Soriano R, Zha JP, Zhang ZM, Modrusan Z, Cunha GR, Gao WQ. 2007. Expression profiling of the mouse prostate after castration and hormone replacement: Implication of $\mathrm{H}$-cadherin in prostate tumorigenesis. Differentiation 75: 219-234.

Wang G, Wang J, Sadar MD. 2008. Crosstalk between the androgen receptor and $\beta$-catenin in castrate-resistant prostate cancer. Cancer Res 68: 9918-9927.

Warso MA, Maniotis AJ, Chen X, Majumdar D, Patel MK, Shilkaitis A, Gupta TK, Folberg R. 2001. Prognostic significance of periodic acid-Schiff-positive patterns in primary cutaneous melanoma. Clin Cancer Res 7: 473-477.

Wheelock MJ, Shintani Y, Maeda M, Fukumoto Y, Johnson KR. 2008. Cadherin switching. J Cell Sci 121: 727.

Wijnhoven BPL, de Both NJ, van Dekken H, Tilanus HW, Dinjens WNM. 1999. E-cadherin gene mutations are rare in adenocarcinomas of the oesophagus. Br J Cancer 80: $1652-1657$.

Wu Y, Starzinski-Powitz A, Guo SW. 2007. Trichostatin A, a histone deacetylase inhibitor, attenuates invasiveness and reactivates E-cadherin expression in immortalized endometriotic cells. Reprod Sci 14: 374-382.

Wyder L, Vitaliti A, Schneider H, Hebbard LW, Moritz DR, Wittmer M, Ajmo M, Klemenz R. 2000. Increased expression of $\mathrm{H} / \mathrm{T}$-cadherin in tumor-penetrating blood vessels. Cancer Res 60: 4682-4688.

Yan Q, Zhanb ZF, Chen XP, Gutmann DH, Xiong M, Xiao ZY, Huang ZY. 2008. Reduced T-cadherin expression and promoter methylation are associated with the development and progression of hepatocellular carcinoma. Int J Oncol 32: 1057-1063.

Yang J, Mani SA, Donaher JL, Ramaswamy S, Itzykson RA, Come C, Savagner P, Gitelman I, Richardson A, Weinberg RA. 2004. Twist, a master regulator of morphogenesis, plays an essential role in tumor metastasis. Cell 117: 927-939.

Yang X, Chen MW, Terry S, Vacherot F, Chopin DK, Bemis DL, Kitajewski J, Benson MC, Guo Y, Buttyan R. 2005. A human- and male-specific protocadherin that acts through the wnt signaling pathway to induce neuroendocrine transdifferentiation of prostate cancer cells. Cancer Res 65: 5263-5271.

Yasuda S, Tanaka H, Sugiura H, Okamura K, Sakaguchi T, Tran U, Takemiya T, Mizoguchi A, Yagita Y, Sakurai T, et al. 2007. Activity-induced protocadherin arcadlin regulates dendritic spine number by triggering N-cadherin endocytosis via TAO2 $\beta$ and p38 MAP kinases. Neuron 56: 456-471.

Yauch RL, Januario T, Eberhard DA, Cavet G, Zhu W, Fu L, Pham TQ, Soriano R, Stinson J, Seshagiri S, et al. 2005. Epithelial versus mesenchymal phenotype determines in vitro sensitivity and predicts clinical activity of erlotinib in lung cancer patients. Clin Cancer Res 11: 8686-8698.

Ying J, Li H, Seng TJ, Langford C, Srivastava G, Tsao SW, Putti T, Murray P, Chan ATC, Tao Q. 2006. Functional epigenetics identifies a protocadherin PCDH10 as a candidate tumor suppressor for nasopharyngeal, esophageal and multiple other carcinomas with frequent methylation. Oncogene 25: 1070-1080. 
Ying JM, Gao ZF, Li HY, Srivastava G, Murray PG, Goh HK, Lim CY, Wang YJ, Marafioti T, Mason DY, et al. 2007. Frequent epigenetic silencing of protocadherin 10 by methylation in multiple haematologic malignancies. $\mathrm{Br}$ J Haematol 136: 829-832.

Yoshiura K, Kanai Y, Ochiai A, Shimoyama Y, Sugimura T, Hirohashi S. 1995. Silencing of the E-cadherin invasion-suppressor gene by $\mathrm{CpG}$ methylation in human carcinomas. Proc Natl Acad Sci USA 92: 7416-7419.

Yu J, Cheng YY, Tao Q, Cheung KF, Lam CN, Geng H, Tian LW, Wong YP, Tong JH, Ying JM, et al. 2009. Methylation of protocadherin 10, a novel tumor suppressor, is associated with poor prognosis in patients with gastric cancer. Gastroenterology 136: 640-651.e1.
Yu JS, Koujak S, Nagase S, Li CM, Su T, Wang X, Keniry M, Memeo L, Rojtman A, Mansukhani M, et al. 2008. PCDH8, the human homolog of PAPC, is a candidate tumor suppressor of breast cancer. Oncogene 27: 4657-4665.

Zbuk KM, Eng C. 2007. Cancer phenomics: RET and PTEN as illustrative models. Nat Rev Cancer 7: 35-45.

Zeng Q, Hong W. 2008. The emerging role of the Hippo pathway in cell contact inhibition, organ size control, and cancer development in mammals. Cancer Cell 13: $188-192$.

Zhao B, Lei QY, Guan KL. 2008. The Hippo-YAP pathway: New connections between regulation of organ size and cancer. Curr Opin Cell Biol 20: 638-646. 


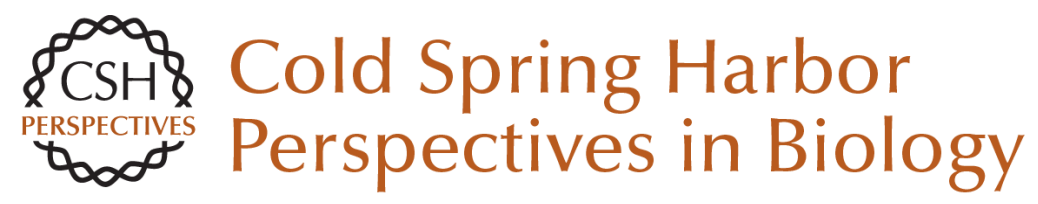

\section{Involvement of Members of the Cadherin Superfamily in Cancer}

Geert Berx and Frans van Roy

Cold Spring Harb Perspect Biol 2009; doi: 10.1101/cshperspect.a003129 originally published online September 23, 2009

\section{Subject Collection Cell-Cell Junctions}

Vascular Endothelial (VE)-Cadherin, Endothelial Adherens Junctions, and Vascular Disease Maria Grazia Lampugnani, Elisabetta Dejana and Costanza Giampietro

Adherens Junctions and Desmosomes Coordinate Mechanics and Signaling to Orchestrate Tissue Morphogenesis and Function: An Evolutionary Perspective Matthias Rübsam, Joshua A. Broussard, Sara A. Wickström, et al.

Cell-Cell Contact and Receptor Tyrosine Kinase Signaling Christine Chiasson-MacKenzie and Andrea I. McClatchey

Hold Me, but Not Too Tight--Endothelial Cell-Cell Junctions in Angiogenesis Anna Szymborska and Holger Gerhardt

\section{Connexins and Disease}

Mario Delmar, Dale W. Laird, Christian C. Naus, et al.

Cell Junctions in Hippo Signaling

Ruchan Karaman and Georg Halder

Loss of E-Cadherin-Dependent Cell-Cell Adhesion and the Development and Progression of Cancer Heather C. Bruner and Patrick W.B. Derksen
Signaling by Small GTPases at Cell-Cell Junctions: Protein Interactions Building Control and Networks Vania Braga

Making Connections: Guidance Cues and Receptors at Nonneural Cell-Cell Junctions Ian V. Beamish, Lindsay Hinck and Timothy E. Kennedy

The Cadherin Superfamily in Neural Circuit Assembly James $D$. Jontes

Mechanosensing and Mechanotransduction at Cell-Cell Junctions Alpha S. Yap, Kinga Duszyc and Virgile Viasnoff

Beyond Cell-Cell Adhesion: Sensational

Cadherins for Hearing and Balance Avinash Jaiganesh, Yoshie Narui, Raul Araya-Secchi, et al.

Cell-Cell Junctions Organize Structural and Signaling Networks Miguel A. Garcia, W. James Nelson and Natalie Chavez

Cell Biology of Tight Junction Barrier Regulation and Mucosal Disease Aaron Buckley and Jerrold R. Turner

For additional articles in this collection, see http://cshperspectives.cshlp.org/cgi/collection/

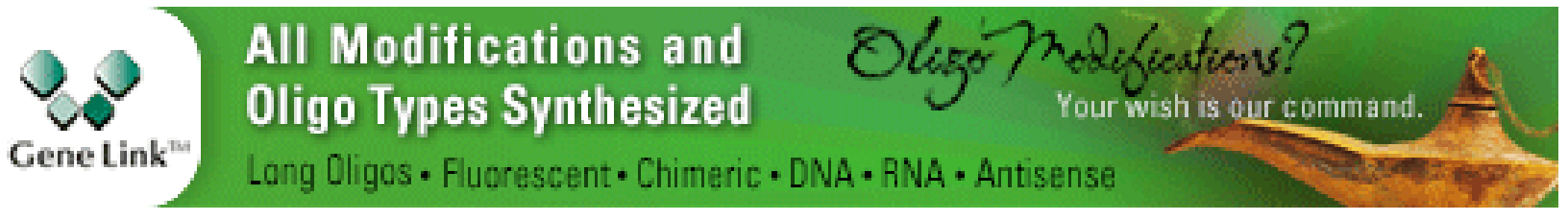


Desmosomes and Intermediate Filaments: Their Consequences for Tissue Mechanics Mechthild Hatzfeld, René Keil and Thomas M. Magin
Integration of Cadherin Adhesion and

Cytoskeleton at Adherens Junctions

René Marc Mège and Noboru Ishiyama

For additional articles in this collection, see http://cshperspectives.cshlp.org/cgi/collection/

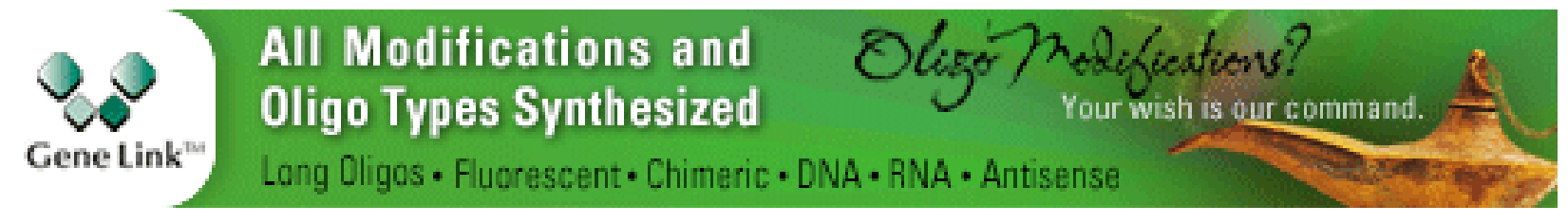

Copyright @ 2009 Cold Spring Harbor Laboratory Press; all rights reserved 